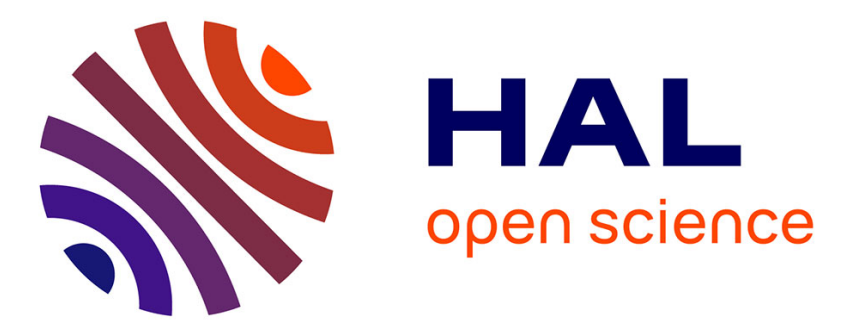

\title{
Emissions of VOCs, SVOCs, and mold during the construction process Contribution to indoor air quality and future occupants' exposure
}

Victoria Gallon, Pierre Le Cann, Mariangel Sanchez, Charline Dematteo, Barbara Le Bot

\section{To cite this version:}

Victoria Gallon, Pierre Le Cann, Mariangel Sanchez, Charline Dematteo, Barbara Le Bot. Emissions of VOCs, SVOCs, and mold during the construction process Contribution to indoor air quality and future occupants' exposure. Indoor Air, 2020, 30 (4), pp.691-710. 10.1111/ina.12647 . hal-02470891

\section{HAL Id: hal-02470891}

https://hal-univ-rennes1.archives-ouvertes.fr/hal-02470891

Submitted on 31 Mar 2020

HAL is a multi-disciplinary open access archive for the deposit and dissemination of scientific research documents, whether they are published or not. The documents may come from teaching and research institutions in France or abroad, or from public or private research centers.
L'archive ouverte pluridisciplinaire HAL, est destinée au dépôt et à la diffusion de documents scientifiques de niveau recherche, publiés ou non, émanant des établissements d'enseignement et de recherche français ou étrangers, des laboratoires publics ou privés. 
DR. BARBARA LE BOT (Orcid ID : 0000-0001-9463-0924)

5 Article type : Original Article

6

7

8 Title: Emissions of VOCs, SVOCs and mold during the construction process: contribution to indoor

9 air quality and future occupants' exposure

10 Running title: Indoor air quality during construction process

11 Authors: Victoria Gallon ${ }^{1}$, Pierre Le Cann ${ }^{1}$, Mariangel Sanchez ${ }^{2}$, Charline Dematteo ${ }^{3}$, Barbara Le Bot ${ }^{1}$

121 Univ Rennes, Inserm, EHESP, Irset (Institut de recherche en santé, environnement et travail) -

13 UMR_S 1085, F-35043 Rennes, France

$14 \quad{ }^{2}$ AQC (Agence Qualité Construction), 29 rue de Miromesnil 75008 Paris, France

$153^{3}$ INDDIGO, 367 avenue du Grand Ariétaz 73024 Chambéry, France

16 Corresponding author:

17 Le Bot, B

18 Univ Rennes, Inserm, EHESP, Irset (Institut de recherche en santé, environnement et travail) -

19 UMR_S 1085, F-35043 Rennes, France

20 barbara.lebot@ehesp.fr

21 Acknowledgments 
22 This project was support by the French Environment and Energy Management Agency (ADEME)

23 (1504C0005). We thank Julien Gastine for sampling and we thank the Environment and Health

24 Research Laboratory (LERES) for the analysis of samples and their contributions to this work. We 25 also thank Nicolas Naulleau and Aurélie Béroudiaux (INTECO society) for the selection and follow-up of construction sites.

\section{Abstract}

Building materials and human activities are important sources of contamination indoors but little information is available regarding contamination during construction process which could persist during the whole life of buildings. In this study, six construction stages on two construction sites were investigated regarding the emissions of 43 volatile organic compounds (VOCs), 46 semivolatile organic compounds (SVOCs) and the presence of 4 genera of mold. Results show that the future indoor air quality does not only depend on the emissions of each building product but that it is also closely related to the whole implementation process. Mold spore measurements can reach $1400 \mathrm{CFU} / \mathrm{m}^{3}$, which is particularly high compared to the concentrations usually measured in indoor environments. Relatively low concentrations of VOCs were observed, in relation to the use of low emissive materials. Among SVOCs analyzed, some phthalates, permethrin, hydrocarbons were found in significant concentrations upon the delivery of building as well as triclosan, suspected to be endocrine disruptor and yet prohibited in the treatment of materials and construction since 2014. As some regulations exist for VOC emissions, it is necessary to implement them for SVOCs due to their toxicity.

Keywords: construction process, dwellings, offices, VOC, SVOC, mold 


\section{Practical implications}

50 The 2012 French Thermal regulation enforces requirements on energy consumption and air 51 permeability of the built envelope. These economic requirements could have consequences on 52 indoor air quality by increasing the concentration levels of pollutants from building materials if 53 they are not associated with an increase in ventilation rates. Results of this study raise questions 54 about indoor air quality management from the early stages of the construction project, which 55 could reduce the indoor air pollution at delivery.

69 People spend about $90 \%$ of their time in closed environments and most of this time occurs at 70 home 1, 2. The Observatory on Indoor Air Quality (OQAI) observed that indoor pollution is 
71 different from outdoor pollution, especially in terms of the presence of some substances that are not detected outdoors or by higher concentrations indoors. In a national survey including 567 French dwellings, it has been demonstrated that the pollutants investigated were present at quantifiable levels in most French dwellings and included physical, chemical and microbiological compounds ${ }^{3}$. Others studies found higher concentrations of pollutants indoors than outdoors, measuring volatile organic compounds (VOCs) ${ }^{4,5}$ or semi-volatile organic compounds (SVOCs) ${ }^{6,7}$. High mold concentrations are also often detected in dwellings 8,9 .

Pollutants found in indoor environments have or are suspected to be related to health adverse effects. VOCs are known to cause respiratory health effects such as asthma or rhinitis ${ }^{10}$ and-are suspected to involve the development of severe diseases as cancer after a long period of inhalation exposure ${ }^{11}$. Formaldehyde is an example of substance classified as carcinogenic for humans by the International Agency for Research on Cancer (IARC) ${ }^{12}$. SVOCs are suspected to have reprotoxic or neurotoxic effects ${ }^{13,14}$. They are emitted from various sources in living environments ${ }^{15}$ and include a wide range of molecules with different properties: pesticides, biocides, plasticizers, flame retardants, surfactants, and lubricants used as active substances or additives. They are present in the gas phase, airborne particles and settled dust ${ }^{16}$, therefore humans are exposed through different pathways including inhalation, ingestion, and dermal contact ${ }^{17}$. Concerning fungal contamination, the presence of mold in dwellings is correlated with the onset of asthma in children and adults ${ }^{18-21}$.

These agents or contamination come from different sources including building materials, furnishings, cleaning supplies and human activities. High VOC concentrations have often been observed in newly built or renovated residential buildings ${ }^{22-24}$. Nevertheless, little information is available regarding the contamination during the construction process which could persist during the whole life of buildings. Even if some authors such as Mendell et al. have alerted the international research community to the risk of contamination of workers during the construction phase ${ }^{25}$, we have focused our study on the potential health effects on future occupants. To our knowledge, only six international publications are available regarding VOC contamination during construction processes in the scope of general population and public 
100 finishing of a new museum in China and suggested that potential contaminant sources were various kinds of wall paints and sprayed glass cleaning agents ${ }^{26}$. Other authors found that the

102 introduction of furniture during the construction process was responsible for emissions of the largest amount of pollutants, including toluene and formaldehyde ${ }^{27,28}$. Liang et al. measured the VOC concentrations during five construction stages of a new apartment and identified the sources of different compounds. Toluene and alpha-pinene increased considerably after the door and doorframe were installed. Likewise, propylene glycol increased after application of the wall paint and benzene after introduction of some furniture ${ }^{29}$. Ochs et al. identified that the door varnishing was responsible for a high emission of butanone and other carbonyl compounds ${ }^{30}$. Plaisance et al. measured the emissions of VOCs at six construction stages in three energyefficient timber-frame houses and found that high $\mathrm{m}, \mathrm{p}$-xylenes and ethylbenzene concentrations at the time of the structural work was due to the emission from the polyurethane adhesive mastic used as a sealing material ${ }^{31}$. They also found that a large number of materials were sources of aldehydes which became the highest proportion in the chemical composition in the last stages of construction. VOC emissions from building materials decrease with time $32,33,34$. Therefore, occupants will be exposed to VOCs emitted by building materials during few months to several years after interior construction was completed, with, for example, secondary aldehyde emissions due to ozone reactions on building materials ${ }^{35}$. Regarding fungal contamination, Sautour et al. conducted a survey in hospital during a period of building construction and found that there were increases in airborne fungal spores at the beginning of construction work and that the most frequently recovered airborne fungi were Penicillium spp., Aspergillus spp. and Bjerkandera adusta ${ }^{36}$. Emissions of mold that have developed during the construction process may persist throughout the life of the building if mold growth occurred on non-visible materials, as drywall ${ }^{37,38}$. These molds, even hidden at the delivery phase, could reappear during the occupation of buildings or remain active behind a lining wall, and could be correlated with the onset of asthma. No studies were found regarding SVOC emissions during construction stages while SVOCs persist several years after the end of the construction process or throughout the life of the building and contribute to the long term exposure of occupants ${ }^{15}$, 39. 
129 In France, some regulations exist regarding the emissions of construction materials. A extremely 130 low emission factor $\left(1 \mu \mathrm{g} / \mathrm{m}^{3}\right)$ has been set for four priority substances (trichloroethylene, 131 benzene, bis(2-ethylhexyl)phthalate and dibutyl phthalate) in order to prevent the producers to 132 add these compounds in their products ${ }^{40}$. A labelling has also been introduced regarding indoor 133 air emissions from construction and decoration products ${ }^{41}$. This labelling indicates the level of 134 VOC emissions, allowing a choice of products that are less harmful to health. Some indoor air 135 quality guidelines (IAGV) exist for some VOCs but no values are available for SVOCs. Moreover, 136 no regulations exist regarding the maximum values of pollutants allowed in the indoor air at 137 delivery of buildings.

138 This project focuses on the impact of the different trades (painter, plasterer, mason, ...) considering differences in process (materials, implementation conditions) and implementation of ventilation equipment to better document the impact of the different construction stages on the

141 air quality at delivery of a building. It is the first time in France that a project aims to measure as many parameters during the different construction stages: VOCs, SVOCs and mold. The objective is to identify the potential sources of pollution that can impact the indoor air quality at the

144 delivery of a building and thus contribute to the exposure of the future occupants to harmful 145 contaminants. 


\section{Materials and measurement design}

Two sites of new construction operations were investigated: an office building and a housing building. The two sites were located in the west part of France (Nantes) in a temperate oceanic climate.

163 Site A consists of the construction of a new office building. The building, with a net internal area 164 (NIA) of $505 \mathrm{~m}^{2}$, is built on two levels: a ground floor and a first floor. The building is based on concrete sails cast in place for vertical structure and prestressed slabs and sail cast in place at the top (including for the high floor) for horizontal structure. Site A was poorly ventilated (few window openings) and a dual-flow ventilation was started just before the last measurement campaign, on July 25, 2016.

Site B consists of the construction of 38 dwellings spread over a set of five buildings.

170 Measurements were carried out in a single building $\left(\mathrm{n}^{\circ} 2\right)$ with a NIA of $600 \mathrm{~m}^{2}$. The building comprises a total of six dwellings spread over three levels: ground floor, first floor and second

172 floor. The construction process includes concrete sails cast in place, prefabricated concrete floors

173 and wood frame facades. The gables in concrete veil benefit from an external insulation and the walls wood frame of a distributed insulation. Site B was more ventilated than site A (window openings) and mechanical ventilation was not used during the measurement campaigns.

176 Contrary to site A, smoking was observed during each visit (principally by the paint company) while this is normally prohibited on construction sites. 
180 Two locations were chosen for the measurements on site A: room A0 on the ground floor and located at the Nord corner of the building and room A1 on the first floor and facing south-east.

Measurements on site B were conducted at three locations: bedroom B0 on the ground floor at the south-east corner, living room B1 on the first floor oriented at the north-west and bedroom B2 on the second floor at the south-east corner. During the implementation of soft floors, measurements were done on the living room on the ground floor instead of B1, to study the impact of the storage of soft floors on the VOC emissions.

Building materials and energy performance

The energy performance of buildings was regulatory according the 2012 French Thermal regulation ${ }^{42}$. Measurements of air permeability were carried out using a Blower Door in accordance with the NF EN 13829 standard. The air permeability of the building envelope was equal to $0.61 \mathrm{~m}^{3} / \mathrm{h} \cdot \mathrm{m}^{2}$ for site $A$ (measured on March 2, 2016) and equal to $0.80 \mathrm{~m} / \mathrm{h} \cdot \mathrm{m}^{2}$ for site $\mathrm{B}$ (measured at the end of construction), under $4 \mathrm{~Pa}$.

All materials and products used have low emissivity with respect to compulsory labelling (class A+ for most of materials and finishing products) ${ }^{41}$.

\section{Construction stages and interest parameters}

Six construction stages were investigated:

1. After the structural work: initial state (walls, roof, exterior joinery, building airtight)

2. During preparation of supports: application of coating and primer paint, implementation of the screed, installation of partitions and linings

3. During the application of finish paints

4. During the implementation of soft floors

5. During the last finishing works: finishing touches, setting up of wood interior joinery, before cleaning

6. At the delivery 
206 Details of the measurement campaigns are presented in Table 1. Site A was investigated from 207 February 22, 2016 to July 27, 2016. Site B was investigated from January 10, 2017 to October 6, 208 2017. Regarding VOCs, 30 measurements were carried out in total on both sites: one 209 measurement at each construction stage in each of the five rooms investigated. Regarding 210 SVOCs, four measurements in total of both sites were carried out: one measurement on the dust 211 of ventilation ducts and one measurement (site A) and two measurements (site B) on $\mathrm{PM}_{10}$. 212 Regarding mold, one mold count on the dust of ventilation ducts was carried out and airborne 213 mold concentrations were measured six times in each of the three rooms investigated of site B 214 and outdoor, and two times in each of the two rooms of site $A$ and outdoor.

43 VOCs, 46 SVOCs and 4 genera of molds were analyzed. List of pollutants is presented in Table

217 2. CAS numbers of VOCs and SVOCs are available in Tables S1-S2. Measurements focused on 218 VOCs commonly studied in indoor environments, measured by OQAI, or VOCs from mandatory labelling on construction products, according to their toxicity. Selection of SVOCs was based on a health-based ranking of SVOCs established according contamination data and reference doses ${ }^{43}$, on published concentrations in indoor environment and on the technical feasibility. Regarding mold measurement, the genera most frequently found in the air and dust of dwellings were studied ${ }^{44}$.

\section{Sampling method}

\section{Ambient parameters}

226 Temperature and relative humidity were measured continuously in each room with recorders HOBOs (Onset, USA), outdoor under a box with three faces behind the construction panel and indoor, attached by a scratch system on the glazing (A0, A1, B0, B1) or attached on a tripod in the center of the room (B2). The time interval of the measurements was 15 minutes.

230 TVOCS

231 Total volatile organic compounds (TVOCs) were measured continuously by a Fireflies station 232 (Hager Services, France), attached on a tripod. This station measured the overall compounds 
233 content with a carbon chain from C3 to C10. Results are expressed as toluene equivalent and 234 take into account the following gases: nitric oxide, nitrogen dioxide, sulfur dioxide, ammoniac

235 and carbon monoxide. The station also measured temperature and relative humidity ${ }^{45}$. The time 236 interval of the measurements was 10 minutes.

\section{Aldehydes}

238 During the two first construction stages on site A, aldehydes were collected during 4 days using 239 commercially available Radiello passive samplers (RAD165, Sigma-Aldrich, Saint-Louis, MO, USA) impregnated with 2,4-dinitrophenylhydrazine (DNPH). The other measurements were active sampling, on Waters Sep-Pak XPoSure cartridges (WAT047205, Waters, Milford, MA, USA) with silice impregnated with DNPH. Air was pumped (Gillian 3500, Sensidyne, St. Petersburg, FL, USA) at a constant flow rate of $500 \mathrm{~mL} / \mathrm{min}$ during $390 \mathrm{~min}$ and the pump was attached on a tripod.

244 Samples were stored at $5{ }^{\circ} \mathrm{C}$ until analysis.

Other VOCs

246 During the two first construction stages on site A, other VOCs were collected during 4 days using 247 commercially available Radiello passive samplers (RAD145, Sigma-Aldrich, Saint-Louis, MO, USA) 248 filled with graphitized charcoal (Carbograph 4). The other measurements were active sampling 249 on tubes filled with adsorbant Carbopack B (20273, Sigma-Aldrich, Saint-Louis, MO, USA) and 250 Carboxen 1000 (10478-U, Sigma-Aldrich, Saint-Louis, MO, USA) with a pump (Gilian LFS 113 251 Sensidyne, St. Petersburg, FL, USA) attached on a tripod at a constant flow rate of $50 \mathrm{~mL} / \mathrm{min}$ 252 during $180 \mathrm{~min}$. Samples were stored at $5^{\circ} \mathrm{C}$ until analysis.

$253 P M_{10}$

254 Airborne $\mathrm{PM}_{10}$ particles were pumped (GilAir-5 pump, Sensidyne, St. Petersburg, FL, USA) at a 255 constant flow rate of 3L/min through a Microvol device (Ecomesure, France) on Teflon filters (47256 $\mathrm{mm}$ diameter and $2 \mu \mathrm{m}$ porosity, Pall Teflo) during 72 hours on site $\mathrm{A}$ and through an impactor on 37-mm quartz fiber filters (TERA Environnement, France) during 96 hours on site B. Samples were stored at $-18^{\circ} \mathrm{C}$ until SVOC analysis. 
260 Dust from ventilation ducts were collected with wipes (ASTM E1792 Lead Wipes, Aramsco, 261 Thorofare, NJ, USA) for the analysis of SVOCs and swabs (020063, Dutscher, France) for the 262 analysis of mold. Before sampling, $1 \mathrm{~mL}$ of saline solution of Tween ${ }^{\circledR} 80$ (Merck KGaA, Darmstadt, 263 Germany) was added to swabs.

Mold

Molds were collected by bio impaction (Sampl'air biocollector, AES laboratory, France). 50 liters of air were impacted on two culture media: Malt Extract Agar (Biokar Diagnostics, France) and Dichloran Glycerol 18\% Agar (Merck KGaA, Darmstadt, Germany) (sampling time: 30 seconds).

\section{Analytical method}

\section{$269 \quad$ Aldehydes}

270 Aldehydes were extracted with acetonitrile $(2 \mathrm{~mL}$ for Radiello samplers and $5 \mathrm{~mL}$ for Waters Sep271 Pak XPoSure cartridges) and analyzed by high-performance liquid chromatography (1260 Infinity 272 liquid chromatography system, Agilent Technologies) coupled to UV detection (1100 Series Diode 273 Array Detector, Agilent Technologies). The analytical method is described by Baurès et al. ${ }^{46}$. 274 Limits of quantification (LOQ) are given in table S3.

\section{Other VOCs}

276 The other VOCs were thermally desorbed (Perkin Elmer ATD Turbo Matrix 150) and analyzed by 277 gas chromatography (7890A, Agilent Technologies) coupled to mass spectrometry (Agilent 278 Technologies 5975C inert XI EI/CI MSD). The analytical method is described by Baurès et al. ${ }^{46}$. 279 LOQ are given in table S4.

\section{SVOCS} SVOCs were desorbed from $\mathrm{PM}_{10}$ and dust by thermal extraction (Gerstel Thermal Desorption Unit TDU 2, Gerstel GmbH \& Co. KG, Mülheim an der Ruhr, Germany) and analyzed by gas chromatography (7890A, Agilent Technologies) coupled to tandem mass spectrometry (70000B Triple Quad, Agilent Technologies). The analytical method is described by Blanchard et al. and Mandin et al. ${ }^{16,47}$. 
287 The cultures were incubated (Friocell, MMM Group, Germany) for 5 to 7 days at room 288 temperature $\left(25^{\circ} \mathrm{C}+/-2^{\circ} \mathrm{C}\right)$ and the fungal thalli were identified from their characteristics 289 observed under optical microscopy ( $\mathrm{CH}-2$, Olympus, Japan) and quantified.

\section{Results}

291 VOCS

292 The VOC concentrations at each construction stage are presented in Table 3. Nine compounds 293 are always under the LOQ: p-tolualdehyde, n-propanol, 1,4-dichlorobenzene, 2-ethoxyethanol, 294 chloroforme, bromodichloromethane, dibromochloromethane, tribromomethane, 295 trichloroethylene and are not presented. The following compounds have between 50 and $70 \%$ of 296 their samples above the LOQ: propionaldehyde, butyraldehyde, valeraldehyde, $n$-decane and $n$ undecane, toluene, styrene, limonene. The following compounds have more than $70 \%$ of their samples above the LOQ: formaldehyde, acetaldehyde, benzaldehyde, hexaldehyde, 299 ethylbenzene, xylenes.

Finish paints, soft floors and last finishing works were the stages with the highest variety of VOCs identified. The application of finish paints was characterized by the highest concentrations of aldehydes. Aromatic hydrocarbons were found during all the construction process. Aliphatic hydrocarbons (n-decane, $n$-undecane) were present during the application of soft floors on site $A$ and these compounds were also found on B2 during the last finishing works. At delivery, glycols ethers and terpenes were identified on site $A$.

Overall, VOC concentrations were higher on site A, especially on A1. This was confirmed by the results of TVOC's measurements (table 4). The implementation of soft floors seemed to be the stage with the highest TVOC levels. TVOC concentrations measured were well above the TVOCs identified levels.

Figure 1 presents the VOC proportions at each construction stage according to the chemical classes. They were calculated by the sum of VOCs in each chemical class divided by the sum of all VOCs measured on the same site/floor. Chemical classes of alcohols, ketones, ethers, 
313 halogenated hydrocarbons, phenols and terpenes are grouped in the category "others" because

314 of the very low concentrations of these compounds. The average concentration at the three

315 floors (ground floor, first floor, second floor) was used for site B while the distinction between 316 the garden ground and the first floor was retained for Site A because of a shift in the progress of 317 construction works. This figure allows to identify the majority chemical classes at each 318 construction phase on each site.

319 Aromatic hydrocarbons and aldehydes were the two main chemical classes of VOCs at the two 320 first construction stages. Aldehydes were the main chemical classes in almost all the other construction stages. During the implementation of soft floors, there were a large amount of

322 aliphatic hydrocarbons. During the last finishing works, aliphatic hydrocarbons were in high concentrations on site B. At delivery, there was an important percentage of glycol ethers on site A.

The evolution of the concentrations of the two main aldehydes measured at delivery is presented in Figures 2 and 3.

On site $A$, a peak of formaldehyde was observed during the application of finish paint, especially on $\mathrm{A} 1$. A second peak was observed on $\mathrm{A} 0$ and $\mathrm{A} 1$ during the last finishing works. Formaldehyde concentrations remained relatively high at delivery despite the start of the ventilation system, contrary to the site $B$ where the ventilation system was not started. On Site B, formaldehyde concentrations started to increase during the application of finish paints and the peak was observed during the implementation of soft floors.

A peak of hexaldehyde was observed on A1 during the application of finish paints. A shift in the application of finish paints was observed between $A 0$ and $A 1$, it explains that a peak was observed on $A 0$ during the implementation of soft floors. On site $B$, levels increased with the implementation of soft floors and the last finishing works to stay relatively high at delivery.

338 Results of SVOC measurements are presented in Table 5. Results with the LOQ of our samples are 339 presented in Table S5. 22 compounds were never quantified above the LOQ: aldrine, dieldrine, 
340 4,4'-DDT, 4-4'-DDE, lindane, alpha-endosulfan, ethyl chlorpyrifos, diazinon, PCBs 28, 31, 52, 101, 105, 118, 138, 153, 180, PBDEs 47, 85, 99, 100, 153.

342 Three polycyclic aromatic compounds (PAHs) were found in the dust from ventilation ducts: 343 fluoranthene, fluorene and phenanthrene. Other PAHs were found on airborne $\mathrm{PM}_{10}$. At each 344 measured stage, phthalates were found in high concentrations on $\mathrm{PM}_{10}$. DiNP and DEHP were 345 predominant. Permethrin was also present. Musks were found on site B, especially at delivery. 346 Triclosan was detected at each measured stage.

Results of mold analysis and associated ambient parameters measured with HOBOs are presented in Table 6.

The first two stages were characterized by a high humidity rate, reaching $80 \%$ on the two sites. During the preparation of supports, concentrations of mold indoor was higher than outdoor, especially on site A with a concentration reaching $1400 \mathrm{CFU} / \mathrm{m}^{3}$ in $\mathrm{A} 1$ when the median percentage of humidity was the highest ( $81 \%$ ). On site B, all genera (Aspergillus, Penicillium, Cladosporium and Alternaria) were in higher concentrations indoor than outdoor. During the application of finish paints, the airborne mold concentrations was twofold higher on $\mathrm{A} 0$, reaching $1000 \mathrm{CFU} / \mathrm{m}^{3}$. At delivery on site $\mathrm{B}$, the mold concentrations indoor were lower than outdoors. All along the construction process, Cladosporium was the most commonly detected genus.

No mold was detected in ventilation ducts during the application of finish paints on ground floor on site $A$ but the presence of mold was revealed on the first floor $\left(1 \mathrm{CFU} / \mathrm{dm}^{2}\right)$.

\section{Discussion}

Overall, concentrations were higher on site A because this construction site was more confined than site B and succession of construction stages was quicker. The comparison between the two sites highlights the importance of natural ventilation, a delay between the sequence of tasks, the 
366 materials and products selection used during the construction process to reduce the 367 concentrations of pollutants in indoor air.

VOCS

370 Concentrations of VOCs measured on site A at delivery were compared to the medians of concentrations measured in office buildings included in the European project OFFICAIR ${ }^{48}$. This

372 European project comprises indoor air quality measurements in office buildings distributed among eight participated countries. 37 office buildings were included in the summer campaign (2012) and 35 in the winter campaign (2012-2013), a total of 148 rooms were investigated.

375 Concentrations of VOCs on site B at delivery were compared to the medians of the annual 376 average concentrations measured in energy-efficient buildings from the OQAl's national indoor 377 air quality reference database ${ }^{49}$. The study was carried out on the basis of validated and 378 complete survey data included in the database on May 2015. 72 dwellings were investigated and 379 they had an average air permeability of $0.54 \mathrm{~m}^{3} /\left(\mathrm{h} . \mathrm{m}^{2}\right)$ for individual houses and 0.86 for collective dwellings to $4 \mathrm{~Pa}$, approximatively as the buildings investigated in this project.

381 The comparison between the concentrations measured in this project and these two other databases are presented in Table 7.

383 For site A, data are of the same order of magnitude between both projects except concentrations 384 of formaldehyde and 2-butoxyéthanol which reached twice the values observed in the project 385 OFFICAIR.

For site B, most of compounds were measured at concentrations of the same order of magnitude of the OQAI's values. Concentrations are four times lower than the OQAI's data for formaldehyde and concentrations of hexaldehyde reached twice the value of OQAI. Concentrations of styrene are much higher than the OQAl's value. Finally, concentrations of limonene are well under the OQAl's value. 
391 The low concentrations of benzene and trichloroethylene may be due to the regulation of 2009 on the conditions for placing on the market construction and decoration products containing carcinogenic, mutagenic and reprotoxic substances ${ }^{40}$.

In this project, the overall compounds content measured with the Fireflies station are well above the sum of each VOCs identified concentrations. It suggests that either gas detection interferes with the measurement or a significant portion of VOCs was not identified in this project. Therefore, for future investigations, it would be necessary to expand measurements to other volatile compounds. Moreover, sensor sensitivity to alcohols (used for disinfection during mold sampling) has been highlighted during the project.

Regarding potential sources of formaldehyde, wood based panels are an important source of formaldehyde ${ }^{50}$. Melamine wood panels have been installed in the sill of all the windows on site A, which could explain the difference of formaldehyde concentrations between the two sites. About hexaldehyde, measured levels at delivery on site B could be linked to the wooden frame façade. Considering their high mobility, VOCs could penetrate through materials and diffuse into buildings. High concentrations of hexaldehyde with wood frame façade has also been observed during air quality measurements at delivery of an eco-district in Langoüet, France ${ }^{51}$. During the measurement campaign carried out during the installation of soft floors, the storage of soft floors in the living room on BO (room used for the storage of soft floors before their installation) does not seem to have had an impact on the concentrations of VOCs in the air, as the concentrations were not different from the measurements in the other rooms. Glycol ethers and

411 limonene present at delivery on site A, were probably emitted by the cleaning products $52,53$. 412 Professional cleaning products were used on site A before delivery for dust removal, removal of 413 stains (cement), labels on certain products, cleaning of floors and glazing and joinery, disinfection 414 of toilets (mainly on site $A$ as it is an establishment open to the public). On site B, less emissive processes were used, including steam cleaning.

In order to assess the potential health impact for future occupants related to the presence and levels of the studied pollutants in indoor air, a comparison with recent guideline values applicable in occupied indoor environments was carried out. Values are reported in Table S6. 
420 the French Agency for Food, Environmental and Occupational Health \& Safety (Anses) ${ }^{54-59}$. In 421 2009, the French High Council for Public Health (HCSP) recommended reference values for 422 management support in confined spaces for new buildings delivered from 2012, as well as to 423 initiate corrective actions if necessary in existing buildings ${ }^{60-61}$. In France, regulatory values have 424 been set for benzene and formaldehyde and must not be exceed indoors ${ }^{62}$.

425 At delivery, concentrations measured are well under the guideline values for acetaldehyde, 426 benzene, ethylbenzene, styrene, toluene and xylenes. The IAGV short term of $100 \mu \mathrm{g} / \mathrm{m}^{3}$ 427 proposed by Anses for formaldehyde has not been exceeded but the concentration on A1 428 reached the regulatory value and the reference value of the HCSP of $30 \mu \mathrm{g} / \mathrm{m}^{3} 61,62$. The value of $42910 \mu \mathrm{g} / \mathrm{m}^{3}$ proposed as target value to be achieved in 10 years by the HSCP was exceeded on AO 430 and A1. In France, this value will be a regulatory value in 2023.

431 On sites $A$ and $B$, with the evolution of construction materials (use of less emissive materials) and 432 with the application of the 2012 French Thermal Regulation and considering the VOCs 433 individually, the measured levels respected the guide values at the delivery of buildings, but not 434 the future regulatory value applicable in 2023. Nevertheless, concentrations measured at 435 delivery (therefore over a short period of time) are compared with guidelines values intended for 436 long-term exposure, such as for formaldehyde and benzene. This is a limitation that is important 437 to note.

438 SVOCS

439 Regarding dust from ventilation ducts, dust can accumulate on ducts during the manufacturing 440 process but also during the various phases of storage, transportation and construction ${ }^{63}$. In this 441 project, PAHs measured in the dust from ventilation ducts probably came from degreasing oils 442 and solvents used in the factory for the manufacture of ventilation ducts, as described by 443 Holopainen et al. and Asikainen et al. ${ }^{64,65}$. This project support the recommendation that ducts 444 should be cleaned and protected against impurities during transport, storage and construction ${ }^{64}$, 445 $66,67$.

446 Regarding $\mathrm{PM}_{10}$, the high concentrations of PAHs measured at delivery on site $\mathrm{B}$ can be explained 447 by the use of tobacco reported on site $B{ }^{68,69}$. Regarding to the high diversity of phthalates, the 
448 dominant plasticizer for flexible polyvinyl chloride flooring was DEHP for many years, but DiNP replaced phthalates such as DEHP, DBP, BBP, due to their potential adverse health effects ${ }^{15,16}$. A

450 restriction of their use was observed in several products in Europe and an emission threshold of

$4511 \mu \mathrm{g} / \mathrm{m} 3$ has been implemented for DEHP and DBP. About pesticides, permethrin is known to be 452 used for wood protection ${ }^{70}$. About antimicrobial agent, triclosan is widely used in various 453 personal care and consumer products ${ }^{71,72}$. No data are available on triclosan concentrations 454 during the construction process but Mandin et al. measured SVOCs on PM10 filters collected 455 over 7 days during a nationwide survey of 285 French dwellings and found that triclosan was one 456 of the major particle-bound SVOCS with a median concentration of $114 \mathrm{pg} / \mathrm{m}^{3} 47$. Measurements 457 were conducted from October 2003 to December 2005. On 2014, it has been banned for use in 458 the treatment of construction products and materials since a decision made by the European 459 Commission ${ }^{73}$. Triclosan is an endocrine disruptor and is associated with reproductive and 460 developmental outcomes in animal and in vitro studies and toxicological studies suggest that it 461 can affect endocrine function and antibiotic resistance in human ${ }^{74}$. In this study, triclosan was 462 found at the three construction stages measured. The source of triclosan has not been identified 463 in this project.

Mold

465 The first stages after the structural work seem to be critical stages in relation to the increase of moisture content. This is related to the increase of mold concentrations which reached and exceeded the value of $1000 \mathrm{CFU} / \mathrm{m}^{3}$ proposed by Anses as abnormal concentration in total molds and requiring professional intervention for remediation ${ }^{75}$.

469 These observations raise questions about the management of moisture on construction sites as 470 long as exposure to mold in a work building was associated with the incidence and exacerbations 471 of occupational asthma for adults and visible mold and mold odor were associated with the 472 development and exacerbations of asthma in children ${ }^{21}$. Moreover, according to Caillaud et al., mold exposure is associated with allergic rhinitis ${ }^{21}$.

474 In a recent study, Reboux et al. analyze indoor fungi by cultures of airborne samples from 1012 475 dwellings ${ }^{76} .908$ patients suffering from rhinitis, conjunctivitis, and asthma were compared to 
476104 controls free of allergies. Reboux et al. stated that a threshold of $495 \mathrm{UFC} / \mathrm{m}^{3}$ of 477 Cladosporium is able to discriminate $90 \%$ of asthmatics. This value is almost reached at different 478 stages suggesting the need of intervention to limit the humidity to avoid development of molds: respect of drying times, add ventilation during the construction stage, protect moisture-sensitive materials (plasterboard, insulation, wood panels, interior wood joinery) ${ }^{66}$.

In France, Ginestet et al. showed fungal contamination in two buildings in use that can be considered low $\left(<100 \mathrm{CFU} / \mathrm{m}^{3}\right)^{77}$. Nevertheless, the authors considered that the very high rate of air exchange inside the buildings may explain these low values. This is in accordance with the BASE study carried out in the United States on 100 offices buildings showing the presence of spores (on average $274 \mathrm{sp} / \mathrm{m}^{3}$ ) and fungi (on average $99 \mathrm{CFU} / \mathrm{m}^{3}$ ) in the indoor environment of office buildings where no known health problems have been demonstrated ${ }^{78}$.

\section{Conclusion}

At delivery, VOCs, SVOCs and mold were detected, including one compound banned on construction products and two compounds with limited emission rates.

- Low concentrations of VOCs were measured at delivery, in relation to the use of low emissive materials (class $\mathrm{A}+$ ): regarding to VOCs, the construction phase involves but does not lead to exceedances of the guide values established to date, but one value exceeded the future regulatory value applicable in 2023.

- 11 PAHs, 6 phthalates, permethrin and triclosan were measured at delivery. There is no exposure limit or emission control on construction sites for SVOCs despite the endocrine disruptive effect of some of these molecules.

- Regarding mold concentrations and humidity rates, the increase of building insulation leads to an increase in humidity rates that can be related to the increased incidence of respiratory diseases, highlighting the need for moisture management measures on construction sites.

Contamination during construction can be linked to all the processes implementation: choice of materials, transportation and storage (impact of weather conditions), construction processes and 
need to be confirmed by more measurements to obtain a better estimate of the distribution of concentrations. Finally, management measures must be implemented in the same time as energy-saving measures to limit the impact of SVOC concentrations or mold growth on indoor air quality and more research must be conducted to assess cumulative exposure to these pollutants and the risk for health of the future occupants.

\section{References}

519 1. Klepeis NE, Nelson WC, Ott WR, et al. The National Human Activity Pattern Survey 520 (NHAPS): a resource for assessing exposure to environmental pollutants. Journal of Exposure 521 Science \& Environmental Epidemiology. 2001;11(3):231-252.

522 2. Matz CJ, Stieb DM, Davis K, et al. Effects of age, season, gender and urban-rural status on 523 time-activity: CanadianHuman Activity Pattern Survey 2 (CHAPS 2). Int J Environ Res Public 524 Health. 2014;11(2):2108-2124.

525 3. Kirchner S, Derbez M, Duboudin C, et al. Indoor air quality in French dwellings. Indoor Air 526 2008. Copenhagen, Denmark 2008:Paper ID 574, 578 pages

527 4. Song G, Yu A, Sakai K, et al. Levels of volatile organic compounds in homes in Dalian, 528 China. Air Quality, Atmosphere \& Health. 2016;10(2):171-181. 
529 5. Bari MA, Kindzierski WB, Wheeler AJ, et al. Source apportionment of indoor and outdoor 530 volatile organic compounds at homes in Edmonton, Canada. Building and Environment. $531 \quad 2015 ; 90: 114-124$.

532 6. Rudel RA, Dodson RE, Perovich LJ, et al. Semivolatile Endocrine-Disrupting Compounds in 533 Paired Indoor and Outdoor Air in Two Northern California Communities. Environmental Science 534 \& Technology. 2010;44(17):6583-6590.

5357 Kristensen K, Lunderberg DM, Liu Y, et al. Sources and Dynamics of Semivolatile Organic 536 Compounds in a Single-Family Residence in Northern California. Indoor Air. 2019;Accepted 537 Author Manuscript.

538 8. Osborne M, Reponen T, Adhikari A, et al. Specific fungal exposures, allergic sensitization, 539 and rhinitis in infants. Pediatric Allergy and Immunology. 2006;17(6):450-457.

540 9. Reboux G, Bellanger AP, Roussel S, et al. Indoor mold concentration in Eastern France. 541 Indoor Air. 2009;19(6):446-453.

542 10. Billionnet C, Gay E, Kirchner S, et al. Quantitative assessments of indoor air pollution and 543 respiratory health in a population-based sample of French dwellings. Environ Res. $544 \quad 2011 ; 111(3): 425-434$.

545 11. Tsai W-T. An overview of health hazards of volatile organic compounds regulated as 546 indoor air pollutants. Reviews on Environmental Health. 2019;34(1):81-89.

547 12. International Agency for Research on Cancer (IARC). IARC Monographs on the Evaluation 548 of Carcinogenic Risks to Humans. Available: https://monographs.iarc.fr/wp549 content/uploads/2018/06/mono88.pdf. Accessed June 25, 2019.

550 13. Fournier K, Glorennec P, Bonvallot N. An exposure-based framework for grouping 551 pollutants for a cumulative risk assessment approach: Case study of indoor semi-volatile organic 552 compounds. Environmental Research. 2014;130:20-28.

553 14. Fournier $\mathrm{K}, \mathrm{Baumont} \mathrm{E}$, Glorennec $\mathrm{P}$, et al. Relative toxicity for indoor semi volatile organic 554 compounds based on neuronal death. Toxicol Lett. 2017;279:33-42.

555 15. Weschler CJ, Nazaroff WW. Semivolatile organic compounds in indoor environments. 556 Atmospheric Environment. 2008;42(40):9018-9040.

557 16. Blanchard O, Glorennec $\mathrm{P}$, Mercier F, et al. Semivolatile organic compounds in indoor air 558 and settled dust in 30 French dwellings. Environ Sci Technol. 2014;48(7):3959-3969. 
559 17. Pelletier $\mathrm{M}$, Bonvallot $\mathrm{N}$, Ramalho $\mathrm{O}$, et al. Indoor residential exposure to semivolatile 560 organic compounds in France. Environ Int. 2017;109:81-88.

561 18. Le Cann P, Bonvallot N, Glorennec $\mathrm{P}$, et al. Indoor environment and children's health: 562 recent developments in chemical, biological, physical and social aspects. Int J Hyg Environ Health. $5632011 ; 215(1): 1-18$.

564 19. Sharpe RA, Bearman N, Thornton CR, et al. Indoor fungal diversity and asthma: a meta565 analysis and systematic review of risk factors. J Allergy Clin Immunol. 2015;135(1):110-122.

$56620 . \quad$ Oluwole O, Kirychuk SP, Lawson JA, et al. Indoor mold levels and current asthma among 567 school-aged children in Saskatchewan, Canada. Indoor Air. 2017;27(2):311-319.

568 21. Caillaud D, Leynaert B, Keirsbulck M, et al. Indoor mould exposure, asthma and rhinitis: 569 findings from systematic reviews and recent longitudinal studies. Eur Respir Rev. 2018;27(148).

57022 Shin SH, Jo WK. Volatile organic compound concentrations, emission rates, and source 571 apportionment in newly-built apartments at pre-occupancy stage. Chemosphere. 572 2012;89(5):569-578.

573 23. Hodgson AT, Rudd AF, Beal D, et al. Volatile organic compound concentrations and 574 emission rates in new manufactured and site-built houses. Indoor Air-Int J Indoor Air Qual Clim. 575 2000;10(3):178-192.

576 24. Jang SK, Ryu JM, Park JH, et al. Comparison of indoor air quality at the pre-occupancy 577 stage in new apartments by two different construction time in Korea. Indoor Air 2008. 578 Copenhagen, Denmark 2008:Paper ID: 93.

579 25. Mendell MJ, Fisk WJ, Kreiss K, et al. Improving the health of workers in indoor 580 environments: priority research needs for a national occupational research agenda. Am J Public 581 Healh. 2002;92(9):1430-40.

582 26. Liu J, Zhai JZ, Pei J, et al. Measurement and Assessment of VOC and Formaldehyde 583 Contamination During the Construction of a New Museum in China. ASHRAE Transactions. 584 2007;113(2):355-361.

585 27. Pang SK, Cho H, Sohn JY, et al. Assessment of the Emission Characteristics of VOCs from 586 Interior Furniture Materials during the Construction Process. Indoor and Built Environment. $587 \quad 2007 ; 16(5): 444-455$. 
28. Park JC, Kwon YC, Jun HD. A Study on the Improvement of Indoor Air Quality of NewlyBuilt Apartment Houses Using Low Emission Building Materials. Journal of Asian Architecture and Building Engineering. 2011;10(1):235-240.

29. Liang W, Wang C, Yang C, et al. Volatile organic compounds in different interior construction stages of an apartment. Building and Environment. 2014;81:380-387.

593 30. Ochs SD, Furtado LD, Cerqueira WV, et al. Characterization of the variation of carbonyl compounds concentrations before, during, and after the renovation of an apartment at Niteroi, Brazil. Environ Sci Pollut Res. 2016;23(15):15605-15615.

596 31. Plaisance $\mathrm{H}$, Vignau-Laulhere J, Mocho P, et al. Volatile organic compounds concentrations during the construction process in newly-built timber-frame houses: source identification and emission kinetics. Environ Sci Process Impacts. 2017;19(5):696-710.

599 32. Liang W, Yang C, Yang X. Long-term concentrations of volatile organic compounds in a 600 new apartment in Beijing, China. Building and Environment. 2014;82:693-701.

33. Herbarth O, Matysik S. Decreasing concentrations of volatile organic compounds (VOC) emitted following home renovations. Indoor Air. 2010;20(2):141-146.

34. Park JS, Ikeda K. Variations of formaldehyde and VOC levels during 3 years in new and older homes. Indoor Air. 2006;16(2):129-135.

605

35. Nicolas $M$, Ramalho $\mathrm{O}$, Maupetit F. Reactions between ozone and building products: Impact on primary and secondary emissions. Atmospheric Environment. 2007;41(15):3129-3138.

36. Sautour M, Sixt N, Dalle F, et al. Prospective survey of indoor fungal contamination in hospital during a period of building construction. J Hosp Infect. 2007;67(4):367-373.

37. Dedesko S, Siegel JA. Moisture parameters and fungal communities associated with gypsum drywall in buildings. Microbiome. 2015;3:71.

38. Cooper AM. Mold susceptibility of rapidly renewable materials used in wall construction. Available: https://core.ac.uk/download/pdf/4276521.pdf. Accessed June 26, 2019.

613 39. Weschler CJ. Changes in indoor pollutants since the 1950s. Atmospheric Environment. 614 2009;43(1):153-169.

40. Legifrance. Arrêté du 28 mai 2009 modifiant l'arrêté du 30 avril 2009 relatif aux conditions de mise sur le marché des produits de construction et de décoration contenant des substances cancérigènes, mutagènes ou reprotoxiques de catégorie 1 ou 2 . Available: 
618 https://www.legifrance.gouv.fr/affichTexte.do?cidTexte=LEGITEXT000020679250. Accessed June $619 \quad 25,2019$.

620 41. Legifrance. Arrêté du 19 avril 2011 relatif à l'étiquetage des produits de construction ou de revêtement de mur ou de sol et des peintures et vernis sur leurs émissions de polluants volatils.

Available:

623 https://www.legifrance.gouv.fr/affichTexte.do?cidTexte=JORFTEXT000023991852\&categorieLien =id. Accessed June 25, 2019.

625

42. Ministère de l'Ecologie, du Développement durable, des Transports et du Logement. Réglementation thermique 2012: un saut énergétique pour les bâtiments neufs. Available: https://www.ecologique-solidaire.gouv.fr/sites/default/files/RT\%202012\%20\%20un\%20saut\%20\%C3\%A9nerg\%C3\%A9tique\%20pour\%20les\%20b\%C3\%A2timents\%20neufs\% 20-\%20Avril\%202011.pdf. Accessed June 25, 2019.

43. Bonvallot N, Mandin C, Mercier F, et al. Health ranking of ingested semi-volatile organic compounds in house dust: an application to France. Indoor Air. 2010;20(6):458-472.

44. Dallongeville A, Le Cann P, Zmirou-Navier D, et al. Concentration and determinants of molds and allergens in indoor air and house dust of French dwellings. Sci Total Environ. 2015;536:964-972.

45. Hager Services Environment. Fiche technique Fireflies. Available: https://pro.hagerservices.fr/wp-content/uploads/sites/2/2017/08/HSE-Fiche-technique-

637 fireflies.pdf. Accessed June 25, 2019.

638 46. Baures E, Blanchard O, Mercier F, et al. Indoor air quality in two French hospitals: 639 Measurement of chemical and microbiological contaminants. Sci Total Environ. 2018;642:168640179.

641 47. Mandin C, Mercier F, Ramalho O, et al. Semi-volatile organic compounds in the particulate 642 phase in dwellings: A nationwide survey in France. Atmospheric Environment. 2016;136:82-94.

643 48. Mandin C, Trantallidi M, Cattaneo A, et al. Assessment of indoor air quality in office 644 buildings across Europe - The OFFICAIR study. Sci Total Environ. 2017;579:169-178.

645 49. Derbez M, Wyart G, Le Ponner E, et al. Indoor air quality in energy-efficient dwellings: 646 Levels and sources of pollutants. Indoor Air. 2018;28(2):318-338. 
647 50. Kim S, Kim J-A, Kim H-J, et al. Determination of formaldehyde and TVOC emission factor 648 from wood-based composites by small chamber method. Polymer Testing. 2006;25(5):605-614.

649 51. Blanchard O. Suivi de la qualité de l'air intérieur dans les habitations de l'éco-lotissement 650 de la Pelousière à Langouët (35) Available: https://www.bruded.fr/wp651 content/uploads/2017/08/rapportlangouet.pdf. Accessed June 27, 2019.

652 52. Nazaroff WW, Weschler CJ. Cleaning products and air fresheners: exposure to primary 653 and secondary air pollutants. Atmospheric Environment. 2004;38(18):2841-2865.

654 53. Gerster FM, Vernez D, Wild PP, et al. Hazardous substances in frequently used 655 professional cleaning products. Int J Occup Environ Health. 2014;20(1):46-60.

656 54. Anses. Proposition de valeurs guides de qualité d'air intérieur : I'acétaldéhyde. Available: 657 https://www.anses.fr/fr/system/files/AIR2013sa0076Ra.pdf. Accessed June 25, 2016.

658 55. Anses. Valeurs guides de qualité d'air intérieur : le benzène. Available: 659 https://www.anses.fr/fr/system/files/AIR2004etVG004Ra.pdf. Accessed June 25, 2019.

660 56. Anses. Proposition de valeurs guides de qualité d'air intérieur : l'éthylbenzène. Available: 661 https://www.anses.fr/fr/system/files/AIR2013SA0136Ra.pdf. Accessed June 25, 2019.

662 57. Anses. Mise à jour de valeurs guides de qualité d'air intérieur : le formaldéhyde. Available: 663 https://www.anses.fr/fr/system/files/AIR2017SA0041Ra.pdf. Accessed June 25, 2019.

664 58. Anses. Proposition de valeurs guides de qualité d'air intérieur : le toluène. Available: 665 666 https://www.anses.fr/fr/system/files/AIR2016SA0043Ra.pdf. Accessed June 25, 2019.

59. European Commission. The INDEX project: critical appraisal of the setting and 667 implementation of indoor exposure limits in the EU. Available: http://publications.jrc.ec.europa.eu/repository/bitstream/JRC31622/1622\%20\%20INDEX\%20\%20EUR\%2021590\%20EN\%20report[1].pdf. Accessed June 25, 2019.

670 60. HCSP. Valeurs repères d'aide à la gestion dans l'air des espaces clos : le benzène. Available: https://www.hcsp.fr/docspdf/avisrapports/hcspr20100616_benzenespclos.pdf.

672 Accessed June 25, 2019.

673 61. HCSP. Valeurs repères d'aide à la gestion dans l'air des espaces clos : le formaldéhyde. 674 Available: https://www.hcsp.fr/docspdf/avisrapports/hcspr20091013_airesclosForm.pdf. 675 Accessed June 25, 2019. 
62. Legifrance. Décret $n^{\circ}$ 2011-1727 du 2 décembre 2011 relatif aux valeurs-guides pour l'air intérieur pour le formaldéhyde et le benzène

Available:

678 https://www.legifrance.gouv.fr/affichTexte.do?cidTexte=JORFTEXT000024909119\&categorieLien $679=$ =id. Accessed July 1, 2019.

680 63. Pasanen P. Emissions from filters and hygiene of air ducts in the ventilation systems of 681 office buildings: University of Kuopio, Department of Environmental Sciences 1998.

64. Holopainen $\mathrm{R}$, Tuomainen $\mathrm{M}$, Asikainen $\mathrm{V}$, et al. The effect of cleanliness control during installation work on the amount of accumulated dust in ducts of new HVAC installations. Indoor Air. 2002;12(3):191-197.

65. Asikainen V, Pasanen P, Liesivuori J. Mineral oil residues on HVAC components: measuring methods. Building and Environment. 2003;38(8):1057-1061.

687 66. AQC. Penser qualité de l'air intérieur en phase chantier - Guide méthodologique 688 Available: $\quad$ http://www.qualiteconstruction.com/sites/default/files/2019-05/PT-Qualite-Air689 Interieur-Phase-Chantier-Guide-Methodologique.pdf. Accessed June 27, 2019.

67. AQC. Penser qualité de l'air intérieur lors de la phase chantier. Available: http://www.qualiteconstruction.com/sites/default/files/2019-05/PT-Qualite-Air-Interieur-PhaseChantier.pdf. Accessed 10 July, 2019.

68. Ding YS, Ashley DL, Watson CH. Determination of 10 Carcinogenic Polycyclic Aromatic Hydrocarbons in Mainstream Cigarette Smoke. Journal of Agricultural and Food Chemistry. 2007;55(15):5966-5973.

69. Vu AT, Taylor KM, Holman MR, et al. Polycyclic Aromatic Hydrocarbons in the Mainstream Smoke of Popular U.S. Cigarettes. Chem Res Toxicol. 2015;28(8):1616-1626.

70. Class TJ, Kintrup J. Pyrethroids as household insecticides: analysis, indoor exposure and persistence. Fresenius' journal of analytical chemistry. 1991;340(7):446-453.

71. Bedoux G, Roig B, Thomas $\mathrm{O}$, et al. Occurrence and toxicity of antimicrobial triclosan and by-products in the environment. Environ Sci Pollut Res Int. 2012;19(4):1044-1065.

72. Halden $\mathrm{RU}$, Lindeman $\mathrm{AE}$, Aiello $\mathrm{AE}$, et al. The Florence Statement on Triclosan and Triclocarban. Environ Health Perspect. 2017;125(6):064501.

73. European Commission. Décision d'éxécution de la commission du 24 avril 2014 705 concernant la non-approbation de certaines substances actives biocides en vertu du règlement 
706 (UE) no 528/2012 du Parlement européen et du Conseil Available: https://eur707 lex.europa.eu/legal-content/FR/TXT/PDF/?uri=CELEX:32014D0227. Accessed June 25, 2019.

708 74. Goodman M, Naiman DQ, LaKind JS. Systematic review of the literature on triclosan and 709 health outcomes in humans. Crit Rev Toxicol. 2018;48(1):1-51.

710 75. Anses. Moisissures dans le bâti Available:

711 https://www.anses.fr/fr/system/files/AIR2014SA0016Ra.pdf. Accessed June 25, 2019.

712 76. Reboux G, Rocchi S, Laboissiere A, et al. Survey of 1012 moldy dwellings by culture fungal 713 analysis: Threshold proposal for asthmatic patient management. Indoor Air. 2019;29(1):5-16.

714 77. Ginestet $A$, Ribot $B$, Henninot $M$, et al. Indoor air quality in two different office buildings715 part 2: Indoor and outdoor airborne particulate levels and air filtration. "Proceedings of Indoor 716 Air 2002 ( $9^{\text {th }}$ International Conference on Indoor Air Quality and Climate) - June 30 - July 5, 2002 717 - Monterey, California - vol 4, pp 494-499

718 78. Tsai FC, Macher J.M. Concentrations of airborne culturable bacteria in 100 large US office 719 buildings from the BASE study. Indoor Air. 2005; 15: 71-81.

723 Tables

724 Table 1 Details of the measurement campaigns realized in air and dust 


\begin{tabular}{|c|c|c|c|c|c|c|}
\hline $\begin{array}{l}\text { Construction } \\
\text { stage }\end{array}$ & $\begin{array}{l}\text { Construction } \\
\text { site }\end{array}$ & $\begin{array}{c}\text { Measurement } \\
\text { campaigns }\end{array}$ & 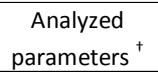 & $\begin{array}{c}\text { Measurement } \\
\text { matrix }\end{array}$ & Location & $\begin{array}{l}\text { Sampling } \\
\text { duration }\end{array}$ \\
\hline \multirow[t]{5}{*}{ Initial state } & $A$ & February 22 to & TVOCs & Air & A1 & Continuously \\
\hline & & 26,2016 & VOCs & Air & $\mathrm{A} 0, \mathrm{~A} 1$ & 5 days \\
\hline & $B$ & January 10, & TVOCS & Air & B2 & Continuously \\
\hline & & 2017 & VOCs & Air & B0, B1, B2 & 6,5 hours \\
\hline & & & Mold & Air & $\begin{array}{c}\text { Outdoor, B0, } \\
\text { B1, B2 }\end{array}$ & 30 seconds \\
\hline \multirow{10}{*}{$\begin{array}{l}\text { Preparation of } \\
\text { supports }\end{array}$} & $A$ & April 4, 2016 & TVOCs & Air & $\mathrm{A} 1$ & Continuously \\
\hline & & & Mold & Air & $\begin{array}{c}\text { Outdoor, A0, } \\
\text { A1 }\end{array}$ & 30 seconds \\
\hline & & April 18 to 22 & TVOCs & Air & $\mathrm{A} 1$ & Continously \\
\hline & & 2016 & VOCs & Air & $\mathrm{A} 0, \mathrm{~A} 1$ & 5 days \\
\hline & $B$ & February 28, & TVOCs & Air & B2 & Continuously \\
\hline & & 2017 & Mold & Air & $\begin{array}{c}\text { Outdoor, B0, } \\
\text { B1, B2 }\end{array}$ & 30 seconds \\
\hline & & April 13, 2017 & TVOCs & Air & B2 & Continuously \\
\hline & & & VOCs & Air & B0, B1, B2 & 6,5 hours \\
\hline & & April 14, 2017 & TVOCs & Air & B2 & Continuously \\
\hline & & & Mold & Air & $\begin{array}{c}\text { Outdoor, B0, } \\
\text { B1, B2 }\end{array}$ & 30 seconds \\
\hline \multirow[t]{9}{*}{ Finish paints } & $A$ & May 13, 2016 & TVOCs & Air & $\mathrm{A} 1$ & Continuously \\
\hline & & & $\begin{array}{l}\text { VOCs (except } \\
\text { aldehydes) }\end{array}$ & Air & $\mathrm{A} 0, \mathrm{~A} 1$ & 180 minutes \\
\hline & & & Mold & Air & $\begin{array}{c}\text { Outdoor, A0, } \\
\text { A1 }\end{array}$ & 30 seconds \\
\hline & & & SVOCs & $\begin{array}{l}\text { Dust from } \\
\text { ventilation } \\
\text { ducts }\end{array}$ & $\begin{array}{l}\text { Ground floor, } \\
\text { first floor }\end{array}$ & - \\
\hline & & & Mold & $\begin{array}{c}\text { Dust from } \\
\text { ventilation } \\
\text { ducts }\end{array}$ & $\begin{array}{l}\text { Ground floor, } \\
\text { first floor }\end{array}$ & - \\
\hline & & May 25, 2016 & TVOCs & Air & A1 & Continuously \\
\hline & & & Aldehydes & Air & $\mathrm{A} 0, \mathrm{~A} 1$ & 390 minutes \\
\hline & B & May 2, 2017 & TVOCs & Air & B2 & Continuously \\
\hline & & & VOCs & Air & B0, B1, B2 & 6,5 hours \\
\hline \multirow[t]{8}{*}{ Soft floors } & $A$ & June 3, 2016 & TVOCS & Air & $\mathrm{A} 1$ & Continuously \\
\hline & & & VOCs & Air & $\mathrm{AO}$ & 6,5 hours \\
\hline & & June 8, 2016 & TVOCs & Air & A1 & Continously \\
\hline & & & VOCs & Air & $\mathrm{A} 1$ & 6,5 hours \\
\hline & $B$ & August 4 to 7 , & TVOCs & Air & B2 & Continuously \\
\hline & & 2017 & VOCs & Air & $\begin{array}{l}\text { B0, B0 living- } \\
\text { room }{ }^{\ddagger}, \text { B2 }\end{array}$ & 6,5 hours \\
\hline & & & Mold & Air & $\begin{array}{c}\text { Outdoor, B0, } \\
\text { B0 living-room, } \\
\text { B2 }\end{array}$ & 30 seconds \\
\hline & & & SVOCs & Airborne $\mathrm{PM}_{10}$ & B2 & 96 hours \\
\hline \multirow{6}{*}{$\begin{array}{l}\text { Last fnishing } \\
\text { works }\end{array}$} & A & June 21 to 24 & TVOCs & Air & A1 & Continuously \\
\hline & & 2016 & VOCs & Air & $\mathrm{A} 0, \mathrm{~A} 1$ & 6,5 hours \\
\hline & & & SVOCs & Airborne $\mathrm{PM}_{10}$ & A1 & 72 hours \\
\hline & B & September 19, & TVOCS & Air & B2 & Continously \\
\hline & & 2017 & VOCs & Air & B0, B1, B2 & 6,5 hours \\
\hline & & & Mold & Air & $\begin{array}{l}\text { Outdoor, B0, } \\
\text { B1, B2 }\end{array}$ & 30 seconds \\
\hline \multirow[t]{6}{*}{ Delivery } & $A$ & July 27, 2016 & TVOCs & Air & $\mathrm{A} 1$ & Continuously \\
\hline & & & VOCs & Air & $\mathrm{A} 0, \mathrm{~A} 1$ & 6,5 hours \\
\hline & $B$ & October 3 to 6 , & TVOCs & Air & B2 & Continuously \\
\hline & & 2017 & VOCs & Air & B0, B1, B2 & 6,5 hours \\
\hline & & & Mold & Air & $\begin{array}{c}\text { Outdoor, B0, } \\
\text { B1, B2 }\end{array}$ & 30 seconds \\
\hline & & & SVOCs & Airborne $\mathrm{PM}_{10}$ & B2 & 96 hours \\
\hline
\end{tabular}

${ }^{\dagger}$ VOCs: volatile organic compounds; SVOCS: semi-volatile organic compounds; TVOCs: total volatile organic compounds; ${ }^{\ddagger}$ Measurement in the living-room on the ground floor 
Table 2 List of pollutants analyzed

\begin{tabular}{|c|c|c|}
\hline \multicolumn{2}{|c|}{ Types of pollutants (number of substances) } & Substances \\
\hline \multicolumn{3}{|c|}{ Chemical } \\
\hline \multirow[t]{11}{*}{ VOCs (43) } & Aldehydes (11) & $\begin{array}{l}\text { - Formaldehyde, acetaldehyde, propionaldehyde, butyraldehyde, benzaldehyde, isovaleraldehyde, valeraldehyde, hexaldehyde, o-tolualdehyde, m-tolualdehyde, p- } \\
\text { tolualdehyde }\end{array}$ \\
\hline & Alcohols (4) & - Ethanol, isopropanol, n-propanol, 2-ethyl-1-hexanol \\
\hline & Ketones (2) & - Acetone, 2-butanone \\
\hline & Chlorobenzenes (1) & -1,4-Dichlorobenzene \\
\hline & Ethers (1) & - Ether \\
\hline & Glycol ethers (3) & -2-butoxyethanol, 2-ethoxyethanol, phenoxyethanol \\
\hline & Aliphatic hydrocarbons (3) & - n-heptane, n-decane, n-undecane \\
\hline & Halogenated hydrocarbons (7) & - Chloroforme, 1,1,1-trichloroethane, trichloroethylene, bromodichloromethane, tetrachloroethylene, dibromochloromethane, tribromomethane \\
\hline & Aromatic hydrocarbons (9) & - Benzene, toluene, ethylbenzene, xylenes $(0, m, p)$, styrene, 1,2,4-trimethylbenzene, naphtalene \\
\hline & Phenols (1) & - Phenol \\
\hline & Terpenes (1) & - Limonene \\
\hline \multirow[t]{11}{*}{ SVOCs (46) } & Phthalates (6) & $\begin{array}{l}\text { - Benzylbutylphthalate (BBP), dibutylphthalate (DBP), di(2-ethylhexyl)phthalate (DEHP), diethylphthalate (DEP), diisononylphthalate (DiNP), diisobutylphthalate } \\
\text { (DiBP) }\end{array}$ \\
\hline & Musks (2) & - Galaxolide, tonalide \\
\hline & Pyerthroids (1) & - Permethrin \\
\hline & Organochlorine pesticides (7) & - Aldrin, dieldrin, 4,4'-DDT, 4,4'-DDE, alpha-ICH, lindane, alpha-endosulfan \\
\hline & Organophosphorous pesticides (2) & - Ethyl chlorpyrifos, diazinon \\
\hline & Others pesticides (1) & - Oxadiazon \\
\hline & Phosphoric esters (1) & - Tributylphosphate \\
\hline & Polycyclic aromatic hydrocarbons (PAHs) (11) & $\begin{array}{l}\text { - Anthracene, benzo[a]pyrene,fluoranthene, fluorene, phenanthrene, pyrene, benzo[b]fluoranthene, benzo[k]fluoranthene, dibenzo[a, h]anthracene, indeno[1,2,3- } \\
\text { cd]pyrene, benzo[a]anthracene }\end{array}$ \\
\hline & Polychlorobiphenyls (PCBs) (9) & - PCB 28, PCB 31, PCB 52, PCB 101, PCB 105, PCB 118, PCB 138, PCB 153, PCB 180 \\
\hline & Polybromodiphenylethers (PBDEs) (5) & - PBDE 47, PBDE 85, PBDE 99, PBDE 100, PBDE 153 \\
\hline & Others (1) & - Triclosan \\
\hline \multicolumn{2}{|c|}{ Microbiological } & \\
\hline \multicolumn{2}{|c|}{ Mold (4) } & - Aspergillus, Penicillium, Cladosporium, Alternaria \\
\hline
\end{tabular}


Table 3 Volatile organic compounds concentrations $\left(\mu \mathrm{g} / \mathrm{m}^{3}\right)$ in air

\begin{tabular}{|c|c|c|c|c|c|c|c|c|c|c|c|c|c|c|c|c|c|c|c|c|c|c|c|c|c|c|c|c|c|c|}
\hline \multirow[t]{2}{*}{ vocs $^{+}$} & \multirow{2}{*}{\multicolumn{30}{|c|}{ Concentrations $\left(\mu \mathrm{g} / \mathrm{m}^{3}\right)^{ \pm}$}} \\
\hline & \multicolumn{5}{|c|}{ Intial state } & \multicolumn{5}{|c|}{ Preparation of supports } & \multicolumn{5}{|c|}{ Finish paints } & & & Soft floors & & & & & & & & & & & & \\
\hline Aldehydes & $A v$ & $A 1$ & & D1 & $D 2$ & $\mathrm{AU}$ & $A_{1}$ & $D U$ & $D 1$ & $D 2$ & AO & $A 1$ & & DI & $B 2$ & $A 0$ & A1 & Bo & Bu(IIVing room) & $B 2$ & Ao & $\mathrm{Al}$ & BO & BI & $B 2$ & & $A 1$ & $B 0$ & BI & $B 2$ \\
\hline Formaldehyde & - & & - & - & - & 5.4 & 6.2 & - & 5.5 & 2.4 & 21.8 & 70.8 & 15.5 & 6.1 & 13.5 & 8.6 & 32.2 & 26.5 & 21.8 & 31.6 & 37.2 & 36.8 & 5.7 & 6.3 & 9.4 & 18.3 & 35.9 & - & 4.5 & 4.8 \\
\hline Acetaldehyde & 2.2 & - & - & - & - & 8.1 & 9.2 & 7.5 & 4.8 & 2.9 & 16.4 & 43.4 & 140.2 & 22.4 & 300.2 & 15.5 & 20 & 10 & 9.7 & 13.6 & 12.1 & 7.9 & 8.6 & 7.3 & 12.5 & 5.6 & 8.6 & 4 & 9.4 & 8.8 \\
\hline Propionaldehyde & & & - & - & 15.7 & & 2.7 & & & & & 22.2 & 2.3 & - & 3.2 & 14.1 & 4.3 & 2.4 & 2.1 & 2.9 & 3.2 & & 2.6 & 3.1 & 4.7 & & & & 2.2 & \\
\hline Butyraldehyde & 10.3 & 10 & & 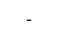 & & - & & 3 & 2.1 & . & - & 12 & 2.5 & - & 6 & 4 & 5.2 & 3.8 & 4.1 & 5.7 & 4.3 & 3.1 & 2.4 & 3 & 4.1 & . & 2.3 & & 8.3 & 11.6 \\
\hline Benzaldehyde & & 1.1 & - & 68.3 & 21.7 & 1.6 & 1.3 & & & - & 3.4 & 6 & 6.4 & 7.3 & 28.9 & - & 13.2 & 15.9 & 8.2 & 8.4 & 7.8 & 3.1 & 3 & 4 & 6.4 & . & - & 3.7 & 11.8 & 10.9 \\
\hline Isovaleraldehyde & - & & - & - & 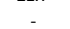 & 2 & 2.3 & - & - & - & & 6.3 & 3.9 & & 6 & - & 2.5 & 7 & 7.3 & & 3.4 & & & & 25 & . & 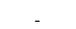 & & 2.9 & 29 \\
\hline Valeraldehyde & - & - & - & - & - & - & t. & - & - & & 4.5 & 63.4 & 7.3 & - & & 14.3 & 15.3 & 5.3 & 5.8 & 9.8 & 6.9 & 4.7 & 4.1 & 5.8 & 7.6 & 3 & 2.7 & & 5.5 & 5.5 \\
\hline Hexaldehyde & - & - & & - & - & 16.3 & 18 & 9.3 & 6.3 & 5.2 & 22.2 & 497.3 & 7.9 & 3.6 & 9.7 & 118.2 & 85.4 & 23.8 & 21.7 & 30 & 26.9 & 15.5 & 32.9 & 41.1 & 53.1 & 7.4 & 8.7 & 11.9 & 44.3 & 38.2 \\
\hline o-Tolualdehyde & NT & NT & & - & - & NT & NT & (5) & . & - & 9.1 & - & - & . & & - & 14.2 & & & 0 & - & - & & 2.3 & 5.1 & - & - & - & - & - \\
\hline $\mathrm{m}$-Tolualdehyde & NT & NT & & - & - & NT & NT & 2.5 & - & - & - & - & - & - & 13.2 & - & - & 3.9 & 3.2 & - & - & - & 2.4 & - & - & - & - & - & - & \\
\hline Alcohols & NT & NT & - & - & - & NT & NT & $-x_{0}$ & $-x_{0}$ & . & $6198^{5}$ & $10073^{5}$ & - & $-x_{0}>$ & 547 & -0 & & $-x_{0}$ & -5 &. & & - & & & - & . & & & & \\
\hline Isopropanol & NT & NT & - & - & - & NT & NT & - & . & - & 1.72 & 7.3 & & & . & - & . & - & - & - & - & & 9.5 & - & 9.3 & - & . & - & - & \\
\hline 2-Ethyl-1-hexanol & NT & NT & - & - & & NT & NT & - & - & - & - & & & & & - & - & - & - & - & 5.67 & & - & - & 16.2 & - & - & & & 7.2 \\
\hline Ketones & NT & & & & & & & & - & D & & & & & & & & & & & & & & & & & & & & \\
\hline $\begin{array}{l}\text { Acetone } \\
2 \text {-butanone }\end{array}$ & NT & NT & 10.34 & - & 581 & NT & NT & - & - & 2.48 & $=0$ & 1.33 & & & - & 873 & -5 & - & - & 5.44 & - & & 1.4 & 1.6 & 15.1 & - & - & - & - & \\
\hline $\begin{array}{l}\text { 2-butanone } \\
\text { Ethers }\end{array}$ & NT & NT & 10.34 & 16.5 & 5.81 & NT & NT & - & - & - & 5.28 & 22.93 & - & & - & 8.73 & 4.63 & - & - & - & - & - & - & - & 20.1 & - & - & - & - & - \\
\hline $\begin{array}{c}\text { Ether } \\
\text { Glycol ethers }\end{array}$ & NT & NT & - & - & - & NT & NT & - & - & - & - & - & - & - & 5.65 & - & - & - & - & - & - & - & - & - & - & - & - & - & - & - \\
\hline $\begin{array}{l}\text { 2-Butoxyethanol } \\
\text { 2-its }\end{array}$ & NT & NT & - & - & - & NT & NT & - & - & - & - & - & & & - & - & - & - & - & - & & & - & - & - & 6.25 & 5.88 & - & & \\
\hline Phenoxyethanol & NT & NT & - & - & - & NT & NT & - & - & - & - & - & & 5.31 & - & - & 10.53 & - & - & - & - & 6.31 & - & - & 6.1 & $>101.01$ & 26.81 & - & & \\
\hline Aliphatic hydrocarbons & & & & & & & & & & & & & & & & & & & & & & & & & & & & & & \\
\hline n-Heptane & NT & NT & - & - & - & NT & NT & - & - & - & - & - & - & & - & - & - & - & - & - & - & - & - & - & 1.4 & - & - & - & - & - \\
\hline n-Decane & NT & NT & - & 1.64 & 4.01 & NT & NT & - & - & - & - & 0.54 & 0.52 & - & 0.59 & 20.3 & 33.06 & - & - & 0.33 & 1.31 & 1.28 & 14.2 & 0.2 & $>22$ & - & - & 0.9 & 0.2 & 8.2 \\
\hline $\mathrm{n}$-Undecane & NT & NT & & 0.71 & 0.81 & NT & NT & - & - & - & - & 0.96 & 0.48 & 0.21 & 0.66 & 20.9 & 27.19 & - & - & 0.56 & 1.44 & 1.37 & 6.3 & & $>22$ & 0.29 & - & 1.1 & 0.2 & 9.9 \\
\hline Halogenated hydrocarbons & & & & & & & & & & & & & & & & & & & & & & & & & & & & & & \\
\hline 1.1.1.-Trichloroethane & NT & NT & - & - & - & NT & NT & - & - & - & - & - & & & - & - & . & - & 0.6 & - & & & - & - & - & - & - & - & & \\
\hline 1.1.2.2.-Tetrachloroethylene & $x_{0}+2$ & 0.2 & - & - & - & & - & - & - & - & & & & & - & - & - & - & - & - & - & & - & - & - & - & - & - & - & \\
\hline $\begin{array}{l}\text { Aromatic hydrocarbons } \\
\text { Benzene }\end{array}$ & 1.48 & 156 & . & - & & 1.69 & 171 & - & - & - & . & & . & - & . & - & . & - & - & 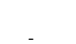 & & 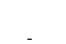 & . & - & 24.17 & . & & . & - & . \\
\hline Toluene & 4.6 & 5.73 & & 0.54 & 0.61 & 4.37 & 5.07 & & & & - & & 0.37 & & 0.27 & 0.62 & & - & - & 2.11 & 0.28 & 0.27 & 2.4 & - & 11.2 & - & 0.98 & 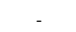 & - & 1.8 \\
\hline Ethylbenzene & 2.61 & 3.11 & 1.62 & 10.75 & 6.26 & 1.81 & 1.93 & 0.51 & 1.01 & 0.26 & . & 0.94 & 1.8 & 0.96 & 3.87 & 4.13 & 2.21 & - & & 2.11 & 0.56 & 0.25 & 2.1 & - & 10.6 & - & - & & - & 1.3 \\
\hline m.p-Xylene & 9.71 & 10.27 & 4.67 & 43.48 & 23.44 & 5.14 & 5.48 & 1.74 & 3.77 & 0.66 & 0.64 & 2.26 & 4.03 & 1.89 & 4.97 & 14.08 & 8.45 & & 0.78 & 9.56 & 1.78 & 0.93 & 8.4 & - & 40.7 & - & - & 0.8 & - & 5.9 \\
\hline o-Xylene & 3.48 & 3.85 & 1.74 & 17.1 & 10.31 & 2.7 & 2.8 & 0.88 & 1.68 & 0.32 & 0.37 & 1.05 & 1.97 & 0.84 & 2.51 & 6.18 & 4.83 & & 0.44 & 5.56 & 0.73 & 0.44 & 4.9 & - & 18 & - & - & 0.6 & - & 3.4 \\
\hline & NT & NT & & 0.88 & 1.09 & NT & NT & 0.26 & & 0.22 & 1.61 & 21.28 & 0.58 & 0.23 & 1.29 & 0.42 & 33.06 & & - & 1 & 0.26 & & 0.4 & - & 2.9 & - & - & 15.1 & 13.5 & $>22$ \\
\hline 1.2.4-Trimethylbenzene & NT & NT & & 0.83 & 2.22 & NT & NT & 0.20 & & & & & & & & 7.95 & 11.11 & - & - & + & 0.83 & 0.65 & 3 & - & 9 & - & - & 0.3 & - & 2.5 \\
\hline Naphtalene & NT & NT & - & act & - & NT & NT & - & & - & - & 0.21 & - & 0.21 & - & - & - & - & - & - & & & - & - & 0.2 & - & - & (a) & - & - \\
\hline $\begin{array}{l}\text { Phenols } \\
\text { Phenol }\end{array}$ & NT & NT & - & - & - & NT & NT & - & - & - & - & - & - & 0.53 & - & - & - & - & - & - & - & - & - & - & 2.1 & 5.34 & 6.25 & - & - & 0.7 \\
\hline Terpenes & $N T$ & $N_{T}$ & & 200 & & $N T$ & NT & & nets & & & 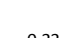 & & & 0 & & & & & & & & & & & & & & & \\
\hline $\begin{array}{c}\text { Limonene } \\
\text { Dofsidentfied }\end{array}$ & NI 34.38 & $\frac{\text { NT }}{35.82}$ & - & 2.69 & 3.18 & $\frac{N T}{4911}$ & $\begin{array}{l}\text { NT } \\
5696\end{array}$ & $\frac{0.39}{26.08}$ & $\frac{0.46}{25.62}$ & $\dot{-}$ & $\frac{-}{8702}$ & 0.33 & $\begin{array}{r}0.55 \\
\end{array}$ & - & $\begin{array}{c}0.5 \\
\end{array}$ & $\frac{-}{25801}$ & -- & 98. & $\frac{-}{8572}$ & $\frac{1.11}{1799}$ & $\frac{-}{11466}$ & $\begin{array}{r}0.41 \\
83.01\end{array}$ & 0.8 & - & $\begin{array}{c}2.1 \\
\end{array}$ & $>20.20$ & $\begin{array}{c}3.52 \\
\end{array}$ & 0.6 & - & $\begin{array}{r}4.8 \\
178 .\end{array}$ \\
\hline
\end{tabular}


Table 4 Total volatile organic compounds, temperature and relative humidity measured with Fireflies station in air during the VOCs measurement campaigns

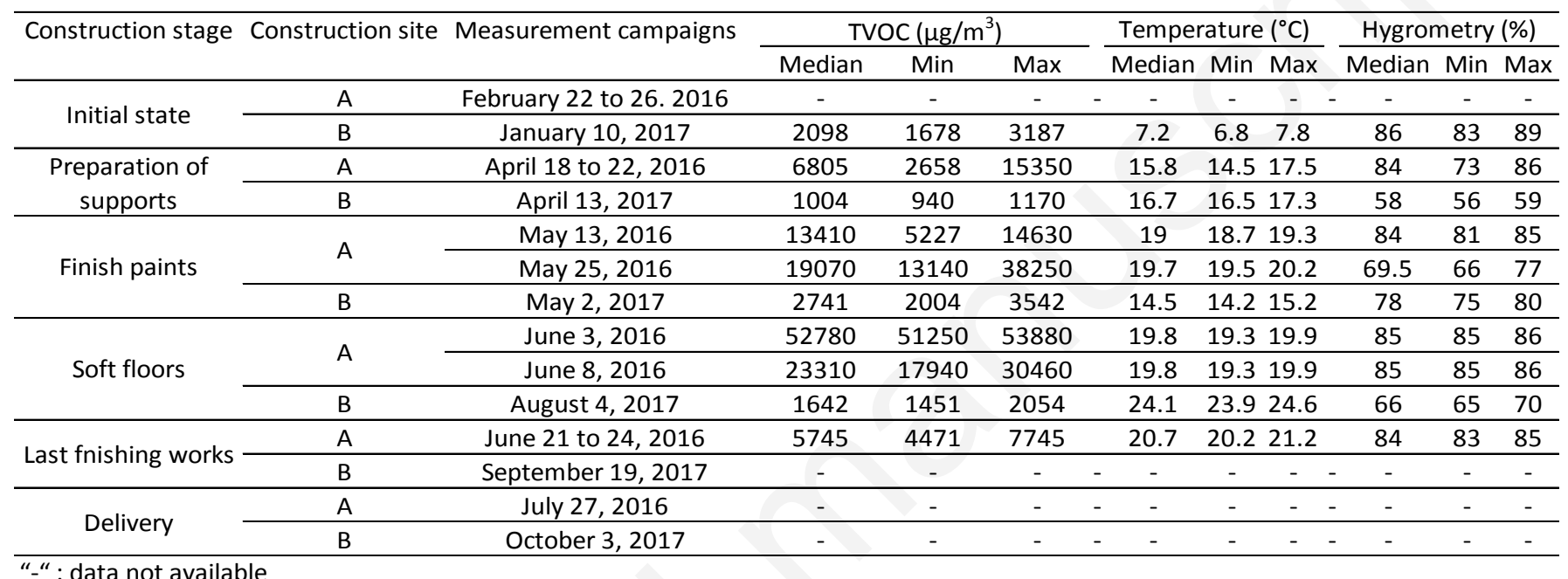

"_" : data not available 
Table 5 Semi-volatile organic compounds concentrations adsorbed on dust from ventilation ducts and adsorbed on airborne particles

\begin{tabular}{|c|c|c|c|c|}
\hline \multirow{3}{*}{ SVOCs $^{\dagger}$} & \multirow{3}{*}{$\begin{array}{c}\begin{array}{l}\text { Dust }^{\ddagger} \\
\text { (ng/g) }\end{array} \\
\text { A } \\
\begin{array}{l}\text { Finish } \\
\text { paints }\end{array}\end{array}$} & \multicolumn{3}{|c|}{ Airbone $\mathrm{PM}_{10}\left(\mathrm{pg} / \mathrm{m}^{3}\right)^{\S}$} \\
\hline & & \multirow{2}{*}{$\begin{array}{c}\text { A1 } \\
\text { Last } \\
\text { finishing } \\
\text { works }\end{array}$} & \multicolumn{2}{|c|}{$\mathrm{B} 2$} \\
\hline & & & Soft floors & Delivery \\
\hline \multicolumn{5}{|l|}{ Phthalates } \\
\hline $\mathrm{BBP}$ & - & - & 379.8 & 495.4 \\
\hline DBP & - & 426 & 740.9 & 11740 \\
\hline DEHP & - & 10440 & 8325 & 26210 \\
\hline DEP & - & - & 2923 & 7352 \\
\hline DiNP & - & $>38580$ & 8798 & 23120 \\
\hline DiBP & - & 185 & 672.7 & 11190 \\
\hline \multicolumn{5}{|l|}{ Musks } \\
\hline Galaxolide & - & - & 43.2 & 127.1 \\
\hline Tonalide & - & - & 8.5 & 29 \\
\hline \multicolumn{5}{|l|}{ Pyerthroids } \\
\hline Permethrin & - & 77 & 16.9 & 41.4 \\
\hline \multicolumn{5}{|l|}{ Organochlorine } \\
\hline Alpha-HCH & - & - & 5.2 & - \\
\hline \multicolumn{5}{|l|}{ Others pesticides } \\
\hline Oxadiazon & - & - & - & 1.4 \\
\hline \multicolumn{5}{|l|}{ Phosphoric esters } \\
\hline Tributylphosphate & - & 39 & - & 174.1 \\
\hline \multicolumn{5}{|l|}{ Polycyclic aromatic } \\
\hline Anthracene & - & 13 & 7 & 19.3 \\
\hline Benzo[a]pyrene & - & 25 & 5.1 & 101.9 \\
\hline Fluoranthene & 50 & 52 & 20.6 & 38.2 \\
\hline Fluorene & 95 & 19 & 26.4 & 50.8 \\
\hline Phénanthrene & 303 & 64 & 37.3 & 50.1 \\
\hline Pyrène & - & 35 & 14.4 & 46.4 \\
\hline Benzo[b]fluoranthe & - & 46 & 14.9 & 128 \\
\hline Benzo[k]fluoranthe & - & 9 & - & 22 \\
\hline Dibenzo[a.h]anthra & - & - & - & 14.7 \\
\hline Indeno[1.2.3- & - & 21 & 8.6 & 142.8 \\
\hline Benzo[a]anthracen & - & 13 & - & 36.3 \\
\hline \multicolumn{5}{|l|}{ Others } \\
\hline Triclosan & - & 38 & 6.5 & 11.1 \\
\hline
\end{tabular}

${ }^{\dagger}$ SVOCs: semi-volatile organic compounds; BBP: benzylbutyl phthalate; DBP: dibutyl phthalate; DEHP: bis(2-ehtylhexyl) phthalate; DEP: diethyl phthalate; DiNP: diisononyl phthalate; DiBP: diisobutyl phthalate; $\alpha-\mathrm{HCH}$ : $\alpha$-hexachlorocyclohexane; PAHs:

polycyclic aromatic hydrocarbons; ${ }^{\ddagger}$ from ventilation ducts; ${ }^{\S} \mathrm{A} 1$ : ground floor site $A$, $\mathrm{B} 2$ : second floor site $\mathrm{B}_{i}$ " - “ : value below limit of quantification 
Table 6 Mold count on dust and airborne mold concentrations with temperature and relative humidity associated

\begin{tabular}{|c|c|c|c|c|c|c|c|c|c|c|c|c|c|}
\hline \multirow[t]{2}{*}{ Construction stages } & \multirow[t]{2}{*}{ Location $^{+}$} & \multirow{2}{*}{$\begin{array}{l}\text { Mold count on } \\
\text { dusts }^{ \pm}\left(\mathrm{CFU} / \mathrm{dm}^{2}\right)\end{array}$} & \multicolumn{5}{|c|}{ Airborne mold concentrations (CFU $/ \mathrm{m}^{3}$ ) } & \multicolumn{3}{|c|}{ Temperature $\left({ }^{\circ} \mathrm{C}\right)$} & \multicolumn{3}{|c|}{ Hygrometry (\%) } \\
\hline & & & Mold & Aspergillus & Penicillium & Cladosporium & Alternaria & Median & Min & Max & Median & Min & Max \\
\hline \multirow{4}{*}{ Initial state } & B outdoor & - & 350 & 100 & $<20$ & 200 & $<20$ & 8.37 & 7.52 & 11.54 & 75.85 & 62.68 & 82.9 \\
\hline & во & - & 510 & $<20$ & 360 & 150 & $<20$ & 7.34 & 6.91 & 10.96 & 76.77 & 62.22 & 78.85 \\
\hline & B1 & - & 230 & 20 & 80 & 110 & 20 & & & - & - & - & - \\
\hline & B2 & - & 240 & 70 & $<20$ & 110 & $<20$ & 7.59 & 6.86 & 11.59 & 77.78 & 58 & 82.85 \\
\hline \multirow[t]{11}{*}{ Preparation of supports } & A outdoor & - & 340 & - & - & - & - & 11.61 & 7.59 & 20.82 & 72.63 & 45.57 & 85.36 \\
\hline & AO & - & 860 & - & - & - & - & 13.22 & 11.35 & 26.18 & 73.72 & 44.59 & 77.86 \\
\hline & A1 & - & 1400 & - & - & - & - & 13.56 & 12.2 & 15.99 & 81.28 & 75.82 & 84.36 \\
\hline & B outdoor Feb 28 & - & 250 & 20 & 50 & 30 & $<20$ & 7.67 & 3.14 & 11.66 & 78.26 & 56.94 & 88.37 \\
\hline & BO Feb 28 & - & 290 & 20 & 170 & 40 & 20 & 9.78 & 8.99 & 10.91 & 81.27 & 78.32 & 85.08 \\
\hline & B1 Feb 28 & - & 670 & 50 & 120 & 390 & 30 & - & - & - & - & - & - \\
\hline & B2 Feb 28 & - & 480 & 50 & 80 & 150 & 30 & 9.39 & 8.47 & 9.93 & 69.47 & 63.74 & 73.41 \\
\hline & B outdoor Apr 14 & - & 510 & 20 & 110 & 320 & 20 & 11.69 & 5.67 & 16.51 & 68.96 & 50.96 & 82.6 \\
\hline & BO Apr 14 & - & 180 & $<20$ & 40 & 100 & $<20$ & 14.76 & 12.92 & 18.94 & 59,00 & 52.74 & 68.94 \\
\hline & B1 Apr 14 & - & 340 & 60 & $<20$ & 220 & $<20$ & 13.86 & 11.86 & 14.53 & 62.04 & 58.27 & 65.52 \\
\hline & B2 Apr 14 & - & 460 & 70 & 50 & 230 & $<20$ & 16.19 & 15.75 & 18.3 & 58.77 & 55.62 & 62.66 \\
\hline \multirow[t]{4}{*}{ Finish paints } & A ground floor & absence & & & & & & & & & & & \\
\hline & $\begin{array}{l}\text { A first floor } \\
\text { A outdoor }\end{array}$ & 1 & 880 & - & - & - & - & 14.18 & 12.92 & 16.56 & 91.25 & 87.77 & 91.61 \\
\hline & $\begin{array}{l}\text { A outdoor } \\
\text { AO }\end{array}$ & $\begin{array}{c}- \\
-\end{array}$ & 1000 & - & _- & - & - & $\begin{array}{l}14.18 \\
17.65\end{array}$ & $\begin{array}{l}12.92 \\
17.15\end{array}$ & $\begin{array}{l}10.56 \\
18.91\end{array}$ & $\begin{array}{l}91.25 \\
75.86\end{array}$ & 72.31 & $\begin{array}{l}1.61 \\
77.32\end{array}$ \\
\hline & $\begin{array}{l}\text { A0 } \\
\text { A1 }\end{array}$ & - & 520 & - & - & - & - & 18.43 & 18.03 & 19.18 & 81.06 & 79.21 & 82.07 \\
\hline \multirow[t]{4}{*}{ Soft floors } & B outdoor & - & 110 & 1 & 2 & 82 & $<1$ & 20.15 & 16.75 & 22.82 & 81.26 & 68.17 & 87.18 \\
\hline & Bo & - & 26 & 3 & 4 & 16 & $<1$ & 22.73 & 22.27 & 23.64 & 69.33 & 66.94 & 74.74 \\
\hline & BO (living-room) & - & 31 & 1 & 3 & 21 & $<1$ & - & - & - & - & - & - \\
\hline & B2 & - & 22 & 2 & 3 & 17 & $<1$ & 24.17 & 23.88 & 24.75 & 64.36 & 61.57 & 67.83 \\
\hline \multirow[t]{4}{*}{ Last finishing works } & B outdoor & - & 990 & $<20$ & 110 & 570 & 30 & - & - & - & - & - & - \\
\hline & BO & - & 500 & 20 & 290 & 150 & 20 & - & - & - & - & - & - \\
\hline & B1 & - & 390 & $<20$ & 50 & 270 & $<20$ & - & - & - & - & - & - \\
\hline & B2 & - & 290 & 20 & 50 & 160 & $<20$ & - & - & - & - & - & - \\
\hline \multirow[t]{4}{*}{ Delivery } & B outdoor & - & $>2000$ & $>2000$ & $>2000$ & $>2000$ & $>2000$ & - & - & - & - & - & - \\
\hline & BO & - & 580 & $<20$ & 60 & 420 & $<20$ & - & - & - & - & - & - \\
\hline & B1 & - & 580 & $<20$ & 60 & 320 & $<20$ & - & - & - & - & - & - \\
\hline & B2 & - & 380 & 20 & 60 & 300 & $<20$ & - & - & - & - & - & - \\
\hline
\end{tabular}


Table 7 Comparison of the concentrations measured in air at delivery with the medians of concentrations measured during the European project OFFICAIR for site A and the medians of the annual average concentrations in dwellings of energy efficient buildings of the OQAl's database for site B

\begin{tabular}{|c|c|c|c|c|c|c|c|c|}
\hline \multirow[b]{2}{*}{$\operatorname{VOCs}^{+}$} & \multicolumn{2}{|c|}{ This project } & \multicolumn{2}{|c|}{ European project OFFICAIR } & \multicolumn{3}{|c|}{ This project } & \multirow[t]{2}{*}{$\begin{array}{l}\text { OQAl's french } \\
\text { database }^{\ddagger}\end{array}$} \\
\hline & AO & A1 & Summer & Winter & BO & B1 & B2 & \\
\hline Formaldehyde & 18.3 & 35.9 & 14 & 7.5 & $<2$ & 4.5 & 4,8 & 17,2 \\
\hline Acetaldehyde & 5.6 & 8.6 & 6.1 & 4.5 & 4 & 9.4 & 8,8 & 11,5 \\
\hline Propionaldehyde & $<1.8$ & $<1.9$ & 2.4 & 1.2 & $<2$ & 2,2 & - & - \\
\hline Benzaldehyde & $<1.8$ & $<1.9$ & 0.9 & $<\mathrm{LOQ}$ & 3.7 & 11,8 & 10,9 & - \\
\hline Hexaldehyde & 7.4 & 8.7 & 10 & 4.4 & 11.9 & 44,3 & 38,2 & 21,3 \\
\hline 1,4-Dichlorobenzene & $<0.2$ & $<0.21$ & - & - & $<0.2$ & $<0,2$ & $<0,2$ & $<L O D$ \\
\hline 2-Butoxyethanol & 6.25 & 5.88 & 2.5 & 0.4 & $<5.6$ & $<5,9$ & $<5,5$ & 1,4 \\
\hline $\mathrm{n}$-Decane & $<0.2$ & $<0.21$ & - & - & 0.9 & 0,2 & 8,2 & 2,3 \\
\hline Trichloroethylene & $<0.2$ & $<0.21$ & $<L O D$ & $<L O D$ & $<0.2$ & $<0,2$ & $<0,2$ & $<L O D$ \\
\hline Tetrachloroethylene & $<0.2$ & $<0.21$ & $<L O D$ & $<L O D$ & $<0.2$ & $<0,2$ & $<0,2$ & $<L O D$ \\
\hline Benzene & $<1.26$ & $<1.30$ & 1 & 1.7 & $<1.39$ & $<1,48$ & $<1,37$ & 1,5 \\
\hline Toluene & $<0.2$ & 0.98 & 4.7 & 3.1 & $<0.2$ & $<0,2$ & 1,8 & 4,8 \\
\hline Ethylbenzene & $<0.2$ & $<0.21$ & 1.1 & 1 & $<0.2$ & $<0,2$ & 1,3 & 1,2 \\
\hline$(\mathrm{m}, \mathrm{p})$-Xylenes & $<0.4$ & $<0.41$ & 2.5 & 2.2 & 0.8 & $<0,5$ & 5,9 & 2,7 \\
\hline o-Xylene & $<0.2$ & $<0.21$ & - & - & 0.6 & $<0,2$ & 3,4 & 1,2 \\
\hline Styrene & $<0.2$ & $<0.21$ & 0.9 & 0.5 & 15.1 & 13,5 & $>22$ & 1,1 \\
\hline Limonene & $>20.20$ & 3.52 & - & - & 0.6 & $<0,2$ & 4,8 & 24,2 \\
\hline
\end{tabular}

Figures

745 Figure 1 Proportions of volatile organic compounds chemical classes in air at each construction stage on site A (ground floor, first floor) and site B 
747 Figure 2 Formaldehyde concentrations in air at each construction stage on site A (ground floor, 748 first floor) and site B (ground floor, first floor, second floor)

749 Figure 3 Hexaldehyde concentrations in air at each construction stage on site A (ground floor, 750 first floor) and site B (ground floor, first floor, second floor) 


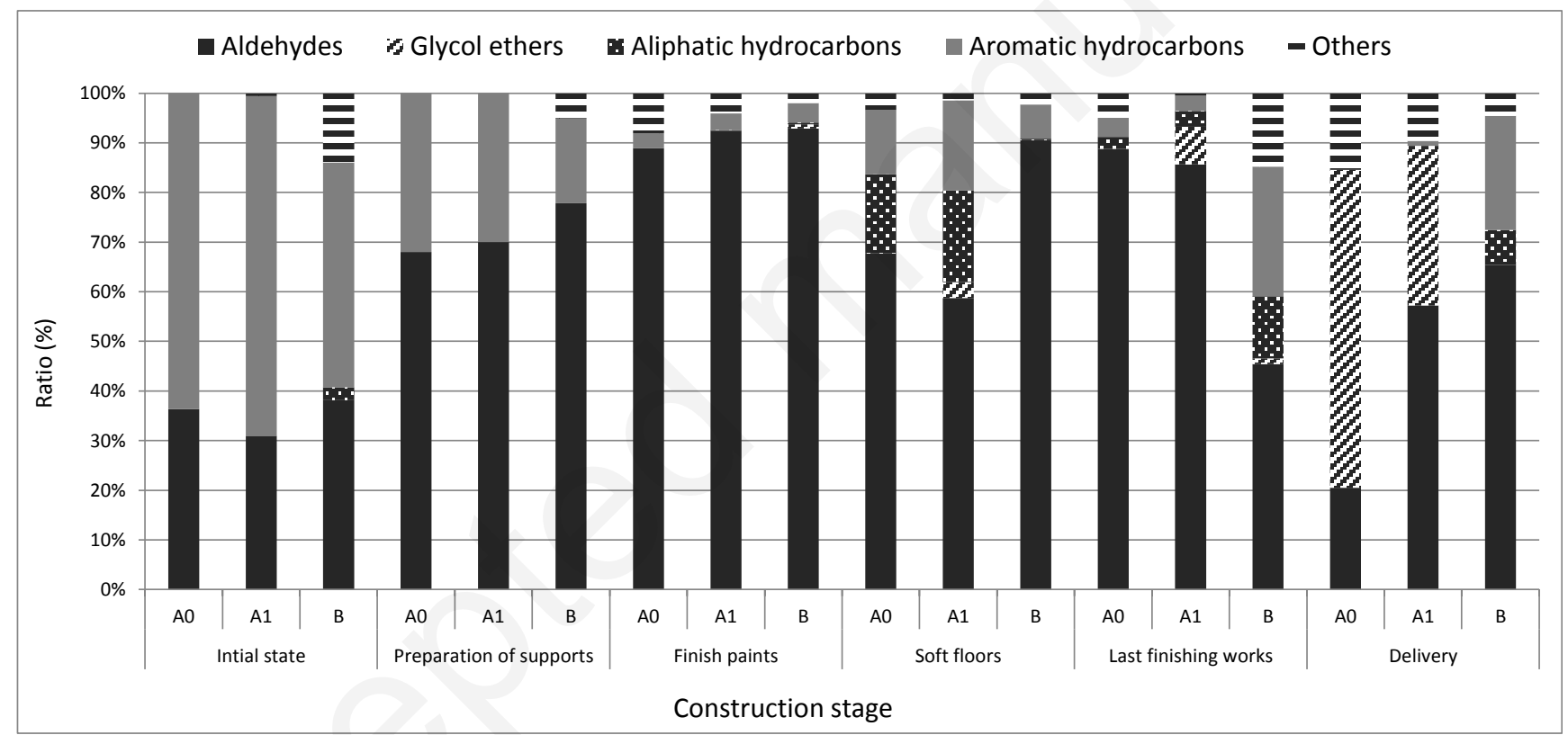




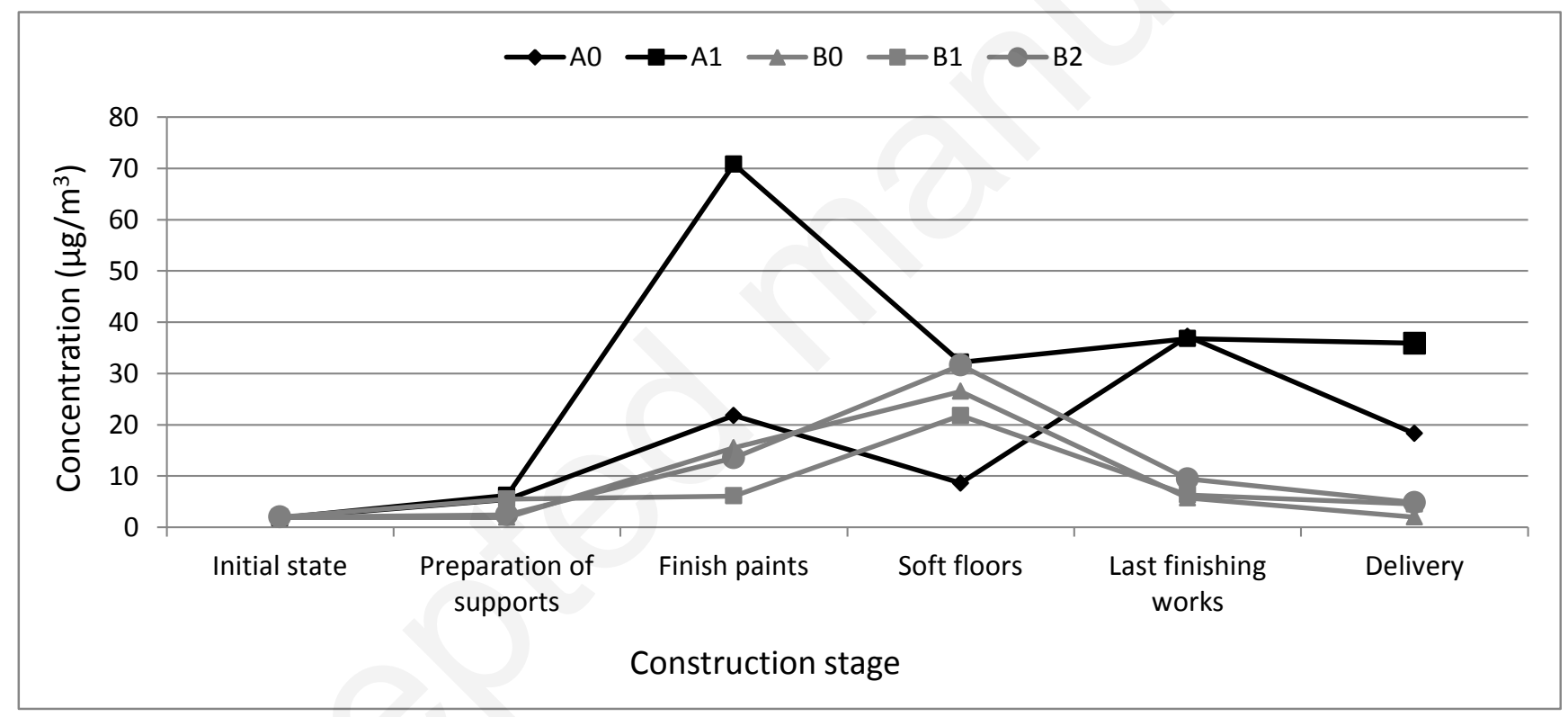




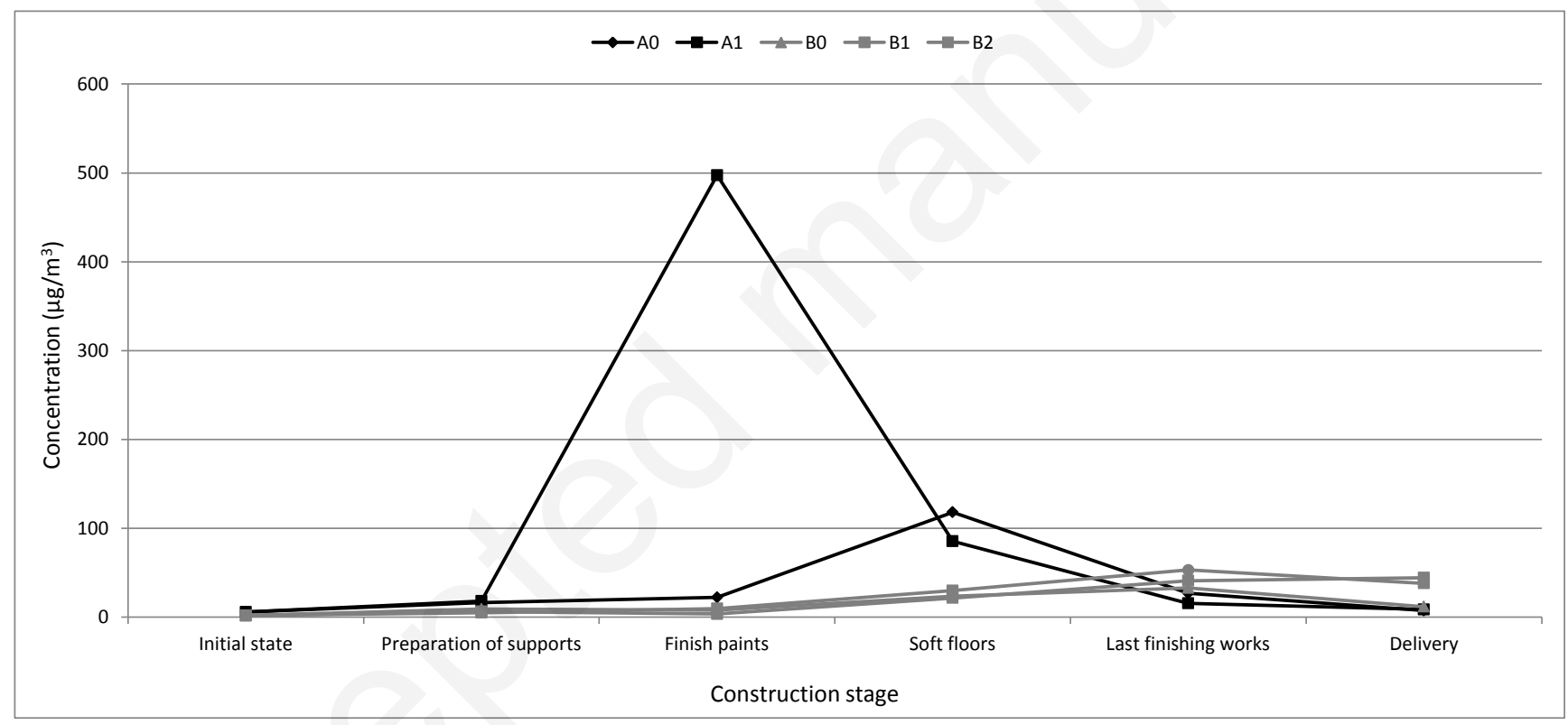

